\title{
Nanopolystyrene beads affect motility and reproductive success of oyster spermatozoa (Crassostrea gigas)
}

\author{
Tallec Kevin 1, ${ }^{\text {}}$, Paul-Pont Ika ${ }^{1}$, Boulais Myrina ${ }^{1}$, Le Goïc Nelly ${ }^{1}$, Gonzalez Fernandez C. ${ }^{1}$, \\ Le Grand Fabienne 1, Bideau Antoine 1, Quéré Claudie 1, Cassone A.-L. 1, Lambert Christophe 1 , \\ Soudant Philippe ${ }^{1}$, Huvet Arnaud 1, ${ }^{*}$
}

\author{
${ }^{1}$ Univ Brest, Ifremer, CNRS, IRD, LEMAR, Plouzané, France \\ * Corresponding authors : Kevin Tallec, email address : kevintallec2@gmail.com ; Arnaud Huvet, email \\ address : arnaud.huvet@ifremer.fr
}

\begin{abstract}
:
Oysters are keystone species that use external fertilization as a sexual mode. The gametes are planktonic and face a wide range of stressors, including plastic litter. Nanoplastics are of increasing concern because their size allows pronounced interactions with biological membranes, making them a potential hazard to marine life. In the present study, oyster spermatozoa were exposed for $1 \mathrm{~h}$ to various doses (from 0.1 to $25 \mu \mathrm{g} \mathrm{mL}-1$ ) of $50-\mathrm{nm}$ polystyrene beads with amine (50-NH2 beads) or carboxyl (50-COOH beads) functions. Microscopy revealed adhesion of particles to the spermatozoa membranes, but no translocation of either particle type into cells. Nevertheless, the $50-\mathrm{NH} 2$ beads at $10 \mu \mathrm{g} \mathrm{mL}-1$ induced a high spermiotoxicity, characterized by a decrease in the percentage of motile spermatozoa $(-79 \%)$ and in the velocity $(-62 \%)$ compared to control spermatozoa, with an overall drop in embryogenesis success $(-59 \%)$. This major reproduction failure could be linked to a homeostasis disruption in exposed spermatozoa. The $50-\mathrm{COOH}$ beads hampered spermatozoa motility only when administered at $25 \mu \mathrm{g} \mathrm{mL}-1$ and caused a decrease in the percentage of motile spermatozoa (-66\%) and in the velocity $(-38 \%)$, but did not affect embryogenesis success. Microscopy analyses indicated these effects were probably due to physical blockages by microscale aggregates formed by the $50-\mathrm{COOH}$ beads in seawater. This toxicological study emphasizes that oyster spermatozoa are a useful and sensitive model for (i) deciphering the fine interactions underpinning nanoplastic toxicity and (ii) evaluating adverse effects of plastic nanoparticles on marine biota while waiting for their concentration to be known in the environment.
\end{abstract}

Keywords : Nanoplastics, oyster, spermatozoa, motility, reproductive success 


\section{Introduction}

In 2017, $348 \mathrm{Mt}$ of plastics were produced by human activities, a substantial increase from the 2 Mt reported in 1950 (PlasticsEurope 2018). This high consumption and the low efficiency of waste management have now led to a huge release of mismanaged items into the ultimate recipient: the oceans (Eriksen et al. 2014, Jambeck et al. 2015). Plastic release from coastal regions was estimated between 4.8 and $12.7 \mathrm{Mt}$ in 2010, and projections forecast an increase of one order of magnitude within the next decade if mitigation measures are not developed (Jambeck et al. 2015). Plastic debris are pervasive in the marine environment due to their strong resistance to UV-light, temperature, mechanical degradation (e.g. wave action) and microorganisms (GESAMP 2015). Their ubiquitous nature in aquatic environments raises significant and critical questions regarding whether plastic contamination is a new planetary boundary threat as well as an unsafe condition for human health (Jahnke et al. 2017, Wright and Kelly 2017).

Global inventories describing the state of this contamination have spotlighted a high amount of small debris termed microplastics (MP; $<5 \mathrm{~mm}$ ). Microplastics $(330 \mu \mathrm{m}-5 \mathrm{~mm})$ constitute $92 \%$ $\left(485 \times 10^{10}\right.$ particles) of the total plastic items estimated at the surface layer of open oceans (Eriksen et al. 2014). However, recent assessments of the abundance of small MP (10 - 330 $\mu \mathrm{m})$ have highlighted the underestimated state of the contamination. More than $90 \%$ of plastic debris exhibited a size smaller than $100 \mu \mathrm{m}$ in surface water and sediments from the southern North Sea (Lorenz et al. 2019), the Artic deep-sediments (Bergmann et al. 2017) and sea ice (Peeken et al. 2018). This is related to the release of small manufactured (primary) MP (e.g., exfoliates, scrubbers) and the uninterrupted weathering of plastic pieces (secondary MP) in seawater down to nanoscale particles; the latter are defined as nanoplastics (NP) for which size limits remain unclear $(<1 \mu \mathrm{m}$ or $<100 \mathrm{~nm}$ ) (Koelmans et al. 2015, Gigault et al. 2018, Hartmann et al. 2019). Recently, Hartmann et al. (2019) proposed a compromise, suggesting the use of the term NP for particles smaller than $100 \mathrm{~nm}$ and sub-MP for particles between 100 $\mathrm{nm}$ and $1 \mu \mathrm{m}$. In addition, primary NP are suspected to enter directly in the environment via wastes of industrial and domestic activities (Zhang et al. 2012, Hernandez et al. 2017). Higher amounts of NP than MP are expected, but the current lack of analytical tools and methods prevents the estimation of their environmental concentrations in the ocean (Huvet et al. 2016, Mintenig et al. 2018, Schwaferts et al. 2019). 
The over-representation of small plastic debris in oceans emphasizes the need for an assessment of their threat to biota and ecosystems (Galgani et al. 2013). Among particle characteristics, the size is suspected to play a major role in potential toxicity for marine life. Harmful effects were recently reported to be higher for NP $(<100 \mathrm{~nm})$ than for MP in terms of survival, lifespan, fecundity, fertilization, and embryo-larval development in aquatic organisms based on studies using model spherical particles of polystyrene (Lee et al. 2013, Jeong et al. 2016, 2017, Tallec et al. 2018). This difference in effects is likely related to nanoparticle properties, and particularly their large surface-to-volume ratio in comparison with bulk material, which promotes high reactivity with biological systems and leads to various effects (cytotoxic, genotoxic, reprotoxic) (Mattsson et al. 2015, Paul-Pont et al. 2018). Moreover, NP have the potential to translocate into tissues/organs as observed in scallop, which could increase their toxicity and bioavailability for higher trophic levels (Al-Sid-Cheikh et al. 2018).

Free-spawning invertebrates are numerous in aquatic environments (Lewis and Ford 2012). At the start of the life cycle, early life stages (ELS) are crucial because they participate actively in the population recruitment, the community structure, and consequently to the ecosystem balance (Lewis and Ford 2012, Reinhardt et al. 2015). Nevertheless, ELS have to face all anthropogenic contaminants, and the current consensus is that ELS are more sensitive than adults (Hutchinson et al. 1998, Gallo and Tosti 2019). In this regard, toxic effects of pesticides, pharmaceutical residuals, hydrocarbons, and nanoparticles on ELS of key marine invertebrates (mainly sea urchins, oysters and mussels) were identified (Ringwood et al. 2010, Kadar et al. 2011, Di Poi et al. 2014, Balbi et al. 2017, Vignier et al. 2017, Gallo et al. 2018, Mai et al. 2018, Tallec et al. 2018).

Among these free-spawning marine species, the Pacific oyster (Crassostrea gigas) is a keystone species in coastal ecosystems due to its ecological roles (e.g., biogeochemical cycles, water quality, and reef building) and economic value for aquaculture (Grabowski et al. 2012, Bayne 2017). Our previous study demonstrated a hampered oyster fertilization following a simultaneous exposition of spermatozoa and oocytes to $50 \mathrm{~nm}$ nanopolystyrene beads displaying amine $\left(50-\mathrm{NH}_{2}\right)$ or carboxylic $(50-\mathrm{COOH})$ functionalizations. The response showed a dose-dependent pattern $\left(0-25 \mu \mathrm{g} \cdot \mathrm{mL}^{-1}\right)$, but the implied toxic pathways were not identified (Tallec et al. 2018). Nevertheless, we suggested various explanations for the observed toxicity, including perturbation of antioxidant defenses, disruption of spermatozoa motility, and membrane destabilization. Moreover, in this previous work, we could not discriminate effect on spermatozoa and oocyte. The aim of the present study was therefore to explore detrimental 
processes specifically in oyster spermatozoa following exposures to the $50-\mathrm{NH}_{2}$ and $50-\mathrm{COOH}$ beads. The effects on sperm motility, reactive oxygen species (ROS) production, survival, membrane integrity/constitution and reproductive success (embryogenesis success) were investigated.

\section{Materials and methods}

\section{Particle characterization}

Spermatozoa were exposed to two types of commercial nanopolystyrene beads (nano-PS; 50 $\mathrm{nm}$; no fluorescent labelling; Bangs Laboratories ${ }^{\circledR} /$ Polysciences): (i) amino-polystyrene (50$\mathrm{NH}_{2}$ ); and (ii) carboxylic-polystyrene (50-COOH). In parallel, the same nano-PS beads, but with a green (excitation $480 \mathrm{~nm}$ and emission $520 \mathrm{~nm} ; 50-\mathrm{NH}_{2}$ ) or an orange (excitation 552 $\mathrm{nm}$ and emission $580 \mathrm{~nm}$; 50-COOH) fluorescent label were used for confocal microscopy observations. The toxicity experiments were performed with non-fluorescent beads to avoid a confounding effect due to a possible leaching of the fluorophores (Catarino et al. 2019, Schür et al. 2019). As described in Tallec et al. (2018), commercial suspensions were stocked in ultrapure water (UW) with surfactant (Tween-20 $0^{\odot} ;<0.1 \%$ ) at $4^{\circ} \mathrm{C}$ prior to the experiments. The Z-average (size; $\mathrm{nm}$ ) and mean surface charge ( $\zeta$-potential; $\mathrm{mV}$ ) of these particles were previously characterized by dynamic light scattering (DLS; nano-Zetasizer ZS; Malvern Instruments; UK) in UW and 1- $\mu \mathrm{m}$ filtered seawater (FSW; pH 8.1 and 34 PSU) (Tallec et al. 2018). Briefly, the 50- $\mathrm{NH}_{2}$ suspension exhibited a positive surface charge (UW: $44.0 \pm 1.5 \mathrm{mV}$; FSW: $15.6 \pm 2.7 \mathrm{mV}$ ) and a nanometer-scale size (UW: $53.3 \pm 2.3 \mathrm{~nm}$; FSW: $96.5 \pm 2.0 \mathrm{~nm}$ ) while the 50-COOH suspension had a negative surface charge (UW: $-62.1 \pm 0.4$; FSW: -13.8 $\pm 0.8)$ and formed micrometer-scale aggregates in FSW $(3735.0 \pm 443.8 \mathrm{~nm})$ in comparison to UW where no aggregation occurred $(55.9 \pm 0.4 \mathrm{~nm})$. In addition, for the present study, the particles were placed in the experimental medium (EM) without spermatozoa (removed by a filtration on $0.2 \mu \mathrm{m}$ ) to test potential effects of seminal fluid components on particle behavior (charge and aggregation state), as described in González-Fernández et al. (2018).

\section{Suspensions of nano-PS for exposures}

Stock suspensions of 50- $\mathrm{NH}_{2}\left(100 \mathrm{mg} \cdot \mathrm{mL}^{-1}\right)$ and 50-COOH $\left(25 \mathrm{mg} \cdot \mathrm{mL}^{-1}\right)$ beads were prepared at $1,000 \mu \mathrm{g} \cdot \mathrm{mL}^{-1}$ in $\mathrm{UW}$ and then diluted to $25,10,1$, and $0.1 \mu \mathrm{g} \cdot \mathrm{mL}^{-1}$ (corresponding to $3.6 \times$ $10^{11}, 1.5 \times 10^{11}$ particles. $\mathrm{mL}^{-1}, 1.5 \times 10^{10}$ and $1.5 \times 10^{9}$ particles. $\mathrm{mL}^{-1}$, respectively) in EM $\left(21^{\circ} \mathrm{C}\right)$ to obtain 9 treatments $(2$ particle types $\times 4$ concentrations +1 control). The use of dose- 
response experiments is recommended to assess harmful effects of small plastic debris in order to determine toxicity thresholds owing to the uncertainties about their current and future environmental concentrations (Koelmans et al. 2017, Paul-Pont et al. 2018). Confounding effects due to the presence of a surfactant (Tween-20, in our case) in the commercial nano-PS suspensions (Pikuda et al. 2018) were avoided by adding Tween-20 (Sigma-Aldrich $®$ ) to the control treatment at an equivalent final concentration to that in the $25 \mu \mathrm{g} \cdot \mathrm{mL}^{-1}$ beads treatment $(0.0001 \%)$.

\section{Gamete collection and exposures}

Mature oysters (18 months old) produced in 2015 according to Petton et al. (2015) were collected in the Marennes-Oléron basin (France) and transferred to the Ifremer experimental facilities (French Research Institute for Exploitation of the Sea) in June 2017. These oysters were acclimatized at $16^{\circ} \mathrm{C}$ in a $350 \mathrm{~L}$ raceway and fed ad libitum on a balanced mixture of two microalgae Isochrysis sp. (Tahitian clone: T-iso; CCAP927/14) and Chaetoceros gracilis (UTEX LB2658) until experiments. Oyster sex was determined under microscope (Olympus BX51; $\times 10-20$ magnification) on a sub-sample of gonads $(50 \mu \mathrm{L})$. The sperm were collected by stripping the gonads of male oysters and sieving the resulting mixture at $100-\mu \mathrm{m}$ to eliminate debris (Steele and Mulcahy 1999). The mixture was diluted in $100 \mathrm{~mL}$ of FSW at $21^{\circ} \mathrm{C}$ for $1 \mathrm{~h}$ to start capacitation (i.e., the final step of maturation occurring in seawater to trigger hyperactivated motility). Spermatozoa concentrations were calculated by flow cytometry (EasyCyte Plus cytometer; Guava Merck Millipore, USA) (Le Goïc et al. 2013) and then set at $10^{7}$ cells. $\mathrm{mL}^{-1}$ in tubes filled with the different nano-PS treatments $\left(0.1,1,10\right.$ and $\left.25 \mu \mathrm{g} . \mathrm{mL}^{-1}\right)$. Exposures lasted $1 \mathrm{~h}$ and were performed on six (for all measures except for lipid analyses; final volume $=3.5 \mathrm{~mL}$ ) and four (for lipid analyses; final volume $=100 \mathrm{~mL}$ ) replicates for each treatment; each replicate corresponding to a pool of spermatozoa from 3 males (total number of male oysters $=18$ ).

\section{Sperm motility and velocity}

After the $1 \mathrm{~h}$ exposure, $25 \mu \mathrm{L}$ of each treatment and replicate were diluted in $475 \mu \mathrm{L}$ of FSW containing pluronic acid (1 g.L. $\mathrm{L}^{-1}$ ) (Boulais et al., 2019). After 10 minutes, $12 \mu \mathrm{L}$ of each suspension were placed in FastRead cells (Fischer Scientific ${ }^{\circledR}$, USA), and the sperm were observed by light microscopy (Olympus BX51, Japan; $\times 20$ magnification with phase contrast) to acquire videos (Camera Qicam Fast 1394, 60 frames.sec ${ }^{-1}, 6$ sec.treatment ${ }^{-1}$ ). Five videos were acquired for each replicate. Videos were analyzed by the ImageJ Software using the 
Computer-Assisted Sperm Analyzer (CASA) plug-in to characterize the percentage of motile spermatozoa (\%) and the Velocity of the Average Path (VAP; $\mu \mathrm{m} \cdot \mathrm{sec}^{-1}$ ) (Wilson-Leedy and Ingermann 2007). The calibration settings developed for oyster spermatozoa are described in Boulais et al. (2015).

\section{Flow Cytometry}

All flow cytometry measurements were performed at the end of the exposures with an EasyCyte Plus cytometer (Guava Merck Millipore, USA), except for the acrosomal integrity, which was characterized using a FACSverse cytometer (BD Biosciences, USA). The two cytometers were equipped with a $488 \mathrm{~nm}$ argon laser; two fluorescence detectors were used with the EasyCyte Plus (green 525/30 nm and red 680/30 nm) and one for the FACSverse (Per-CP-Cy5.5-A 700/54 $\mathrm{nm}$ ). The relative cell size and complexity were estimated based on the forward scatter (FSC) and side scatter (SSC) values (U.A.) (Le Goïc et al. 2013).

The spermatozoa membrane integrity was assessed with the "Live/Dead Sperm Viability kit" (Molecular Probes ${ }^{\circledR}$, USA) according to Le Goïc et al. (2013). Briefly, $10^{6}$ spermatozoa were sampled and stained with SYBR-14 (final concentration $1 \mu \mathrm{M}$ ) and propidium iodide (PI; final concentration $10 \mu \mathrm{g} . \mathrm{mL}^{-1}$ ) for 10 minutes in dark condition at room temperature. This dualstaining allows a measurement of the percentage of live and dead spermatozoa; the SYBR-14 penetrates only cells without membrane damage (live spermatozoa; green detector), while the PI only enters into cells that have lost membrane integrity (dead spermatozoa; red detector) (Garner and Johnson 1995). Results were expressed as the percentage of live spermatozoa (\%).

Intracellular reactive oxygen species (ROS) production was determined by incubating $10^{6}$ spermatozoa with 2',7'-dichlorofluorescein diacetate (DCFH-DA; final concentration $10 \mu \mathrm{M}$; Sigma-Aldrich $^{\circledR}$ ) for 50 minutes in dark condition at room temperature. DCFH-DA is hydrolyzed in the cells by esterases to form the DCFH, which emits a green fluorescence after oxidation by ROS to DCF (Lambert et al. 2003). The relative amount of ROS in cells was expressed as the mean level of green fluorescence (A.U.; green detector).

A posteriori, the acrosomal integrity was verified using the protocol of Volety et al. (2016) in control samples and in treatments that affected the spermatozoa's reproductive success. A sample of $2 \times 10^{5}$ spermatozoa was incubated with the LysoTracker Red DND-99 (Molecular Probes ${ }^{\circledR}, \mathrm{USA}$; final concentration $1 \mathrm{mM}$ ) for 10 minutes in dark condition at room temperature. This probe specifically stains the acrosome, which is an acidified organelle (Volety et al. 2016). 
A loss of acrosomal integrity is characterized by a decrease in the mean level of red fluorescence (A.U.; Per-CP-Cy5.5-A detector).

\section{Lipid analyses}

Lipid analyses were performed only on spermatozoa from the control and treatments that affected the spermatozoa motility. Samples $\left(2.5 \times 10^{9}\right.$ spermatozoa.treatment $\left.^{-1} ; \mathrm{n}=4\right)$ were collected on GF/F glass-fiber filters $\left(0.2 \mu \mathrm{m}\right.$; Whatman $\left.{ }^{\circledR}\right)$ and then extracted in $6 \mathrm{~mL}$ chloroform: methanol (2:1 v/v), according to a procedure modified from Folch et al. (1957) (Da Costa et al. 2016). Samples were flushed with nitrogen gas and stored at $-20^{\circ} \mathrm{C}$ until analyses. All materials were rinsed with acetone and/or burnt for $6 \mathrm{~h}$ at $450^{\circ} \mathrm{C}$ before use to prevent contamination; all chemicals were HPLC grade.

\section{Analyses of lipid classes}

Lipid classes were separated by high-performance thin layer chromatography (HPTLC). Two HPTLC glass plates coated with silica $\left(200 \times 100 \mathrm{~mm}\right.$; Merck ${ }^{\circledR} 60$, Germany) were used: one to separate neutral lipids (NL) and the other to separate polar lipids (PL). The HPTLC plates were first cleaned with a mixture of methyl acetate:isopropanol:chloroform:methanol: $\mathrm{KCl} 0.25 \%$ (10:10:10:4:3.6; v/v) for PL and with hexane:diethyl ether (97:3; v/v) for NL according to Da Costa et al. (2016). Plates were activated at $120^{\circ} \mathrm{C}$ for $30 \mathrm{~min}$ (TLC Plate Heater, CAMAG ${ }^{\odot}$; Switzerland) and lipid extracts ( $2 \mu \mathrm{L}$ for PL and $5 \mu \mathrm{L}$ for NL) were spotted on them with an automatic TLC sampler ATS4 (CAMAG $\left.{ }^{\odot}\right)$. The PL were separated in a solution of methyl acetate:isopropanol:chloroform:methanol: $\mathrm{KCl} 0.25 \% \quad(10: 10: 10: 4: 3.6 ; \mathrm{v} / \mathrm{v})$. The NL were separated by 2 successive developments, first using a mixture of hexane: diethyl ether:acetic acid (20:5:0.5; v/v), followed by a solution of hexane:diethyl ether (97:3; v/v). Lipid classes were revealed by immersion of the plates in a solution containing $3 \% \mathrm{CuSO}_{4}$ and $8 \% \mathrm{H}_{3} \mathrm{PO}_{4}$ (w/v in distilled water) and heated at $180^{\circ} \mathrm{C}(30 \mathrm{~min})$. Data was acquired using a scanner densitometer at $370 \mathrm{~nm}$ (TLC Scanner $4 \mathrm{CAMAG}^{\odot}$ ). The results were analyzed with the WinCATS software $\left(\mathrm{v} 2.4\right.$ CAMAG $\left.^{\odot}\right)$ by comparing the retention time and intensity of bands related to each class against known standards (Moutel et al. 2016). The lipid classes were expressed as the mass percentage of each class to the total lipid content which was expressed in $\mathrm{mg}$ per $10^{9}$ spermatozoa. Nine classes were identified: 3 NL classes (triglycerides, sterols and free fatty acids) and 6 PL classes (phosphatidylcholine [PC], phosphatidylethanolamine [PE], phosphatidylinositol + ceramide amino-ethylphosphonate [PI+CAEP], phosphatidylserine [PSer] and cardiolipin [CL]). Triglycerides correspond to storage lipids and free fatty acids is considered as a proxy of lipid degradation. Sterols, PE, PSer, PI+CAEP, and 
CL constitute membrane lipids. The PC/PE ratio was used as a proxy for the membrane stability (Li et al. 2006).

Analyses of fatty acids (FA)

To determine FA composition of neutral and polar lipid fractions, $1 \mathrm{~mL}$ of lipid extracts was evaporated to dryness under $\mathrm{N}_{2(\mathrm{~g})}$ and then resuspended in $3 \times 500 \mu \mathrm{L}$ of chloroform:methanol $(98: 2 ; \mathrm{v} / \mathrm{v})$. Samples were deposited at the top of a micro-column $(40 \times 5 \mathrm{~mm})$ using silica gel 60 previously heated for $6 \mathrm{~h}$ at $450^{\circ} \mathrm{C}$ and moistened with $6 \%$ deionized water (Le Grand et al. 2014). Thereafter, PL and NL fractions were eluted and separated by passing $10 \mathrm{~mL}$ of methanol:chloroform (98:2; v/v) and $20 \mathrm{~mL}$ of methanol, respectively, through the column. An internal standard (free fatty acid 23:0, $2.3 \mu \mathrm{g}$ ) was added at this point to quantify fatty acids in samples (Da Costa et al. 2016). The eluted fractions were transesterified to obtain fatty acid methyl esters (FAME): each fraction was evaporated to dryness under $\mathrm{N}_{2(\mathrm{~g})}$, resuspended in 800 $\mu \mathrm{L}$ of $\mathrm{MeOH}-\mathrm{H}_{2} \mathrm{SO}_{4}(3.4 \% \mathrm{v} / \mathrm{v})$, and heated at $100^{\circ} \mathrm{C}$ for $10 \mathrm{~min}$. Hexane $(0.8 \mathrm{~mL})$ and distilledwater saturated with hexane $(1.5 \mathrm{~mL})$ were added, and the aqueous phase was removed after centrifugation $\left(738 \times g ; 60 \mathrm{sec} ; 20^{\circ} \mathrm{C}\right)$. The FAME were rinsed twice with distilled-water saturated with hexane $(1.5 \mathrm{~mL})$. Finally, FAME were analyzed to determine the FA composition of each fraction with a Varian CP8400 gas chromatograph (HP, USA) (parameters are described in Mathieu-Resuge et al. (2019)). The FA composition was expressed as the mass percentage of each FA to the FA content per fraction (neutral and polar).

\section{Microscopy analyses}

\section{Transmission electron microscopy}

Transmission electron microscopy (TEM; JEOL 100 CXII, Japan) observations were performed to assess the potential fine interactions between nano-PS beads and spermatozoa, including translocation, as well as the integrity of the internal structures (nucleus, mitochondria, acrosome, and flagellum) of oyster spermatozoa according to Suquet et al. (2010). An aliquot of spermatozoa from the control treatment and from the highest exposed concentration (25 $\mu \mathrm{g} \cdot \mathrm{mL}^{-1}$ ) for both $50-\mathrm{NH}_{2}$ and $50-\mathrm{COOH}$ beads were immersed in successive buffers: (1) $6 \%$ glutaraldehyde:7\% NaCl:0.4 M cacodylate (2:1:1; v/v) for $2 \mathrm{~h}$ (2) $0.4 \mathrm{M}$ cacodylate:8\% $\mathrm{NaCl}: U W(1: 1: 2 ; \mathrm{v} / \mathrm{v})$ with three successive $15 \mathrm{~min}$ baths (3) $4 \%$ osmium tetroxide:0.4M cacodylate: $10 \% \mathrm{NaCl}$ : UW (1:1:1:1; v/v) for $1 \mathrm{~h}$. The samples were centrifugated $(100 \times g, 10$ min, $4^{\circ} \mathrm{C}$ ) between each step to remove the buffers. The samples were then embedded in $1 \%$ agar and dehydrated in successive mixtures: (1) $50 \% \mathrm{EtOH}$ (15 min); (2) 70\% EtOH (30 min); 
(3) $90 \% \mathrm{EtOH}$ (3 baths of $10 \mathrm{~min}$ ); (4) 100\% EtOH (3 baths of $10 \mathrm{~min}$ ); (5) propylene oxide 99\% ( 3 baths of $10 \mathrm{~min}$ ). Ultimately, the samples were embedded in hard resin (Embed 812 kit; Electron Microscopy Sciences ${ }^{\circledR}$ ), cut into ultrathin sections (70 $\mathrm{nm}$ ), and double stained with lead citrate $\left(250 \mathrm{mg} \cdot \mathrm{mL}^{-1}\right)$ and uranyl acetate $(7 \%)$ before observations.

\section{Scanning electron microscopy}

Scanning electron microscopy (SEM; FEI QUANTA 200, USA) observations were performed to identify potential external modifications of spermatozoa during exposures to nano-PS beads. An aliquot of spermatozoa from the control treatment and the highest exposed concentration (25 $\mu \mathrm{g} \cdot \mathrm{mL}^{-1}$ ) for both $50-\mathrm{NH}_{2}$ and $50-\mathrm{COOH}$ beads were immersed in a mixture of $6 \%$ glutaraldehyde:7\% NaCl:0.4M cacodylate $(2: 1: 1 ; \mathrm{v} / \mathrm{v})$ for $2 \mathrm{~h}$. The samples were then dehydrated in a graded EtOH series (50\%, 70\%, 90\% and 100\%; 10 min each) and desiccated in a critical-point dryer (Leica CPD 300; Germany). Lastly, samples were coated with gold using an SCD 040 sputter coater (Blazers, Liechtenstein).

\section{Confocal microscopy}

A confocal laser scanning microscope (CLSM; Zeiss LSM 780, Germany) was used to observe the interactions between fluorescent nano-PS beads and spermatozoa. An aliquot of spermatozoa exposed to fluorescent $50-\mathrm{NH}_{2}$ or $50-\mathrm{COOH}\left(25 \mu \mathrm{g} \cdot \mathrm{mL}^{-1}\right)$ beads, following the same experimental design as the toxicity experiments was sampled after $1 \mathrm{~h}$ of exposure and fixed with $6 \%$ glutaraldehyde at $4^{\circ} \mathrm{C}$ for $48 \mathrm{~h}$. An excitation/emission of $488 \mathrm{~nm} / 543 \mathrm{~nm}$ was used to visualize the $50-\mathrm{NH}_{2}$ beads and an excitation/emission of $514 \mathrm{~nm} / 612 \mathrm{~nm}$ for $50-\mathrm{COOH}$ beads. Spermatozoa were stained with 1\% DAPI (40,6-diamidino-2-phenylindole; $10 \mathrm{~min}$ in dark condition; excitation/emission $405 \mathrm{~nm} / 455 \mathrm{~nm}$ ) to perform three-dimensional observations.

\section{Assessment of the reproductive success}

At the end of the exposure, spermatozoa from each treatment and replicate were placed in $2 \mathrm{~L}$ glass beakers filled with 1.5 L of clean FSW containing 20,000 control oocytes pooled from 3 females per replicate $(n=6$ replicates; total number of female oysters $=18$ ). The oocytes were collected by stripping the gonads and sieving at $100 \mu \mathrm{m}$ and then $20 \mu \mathrm{m}$ with sterile equipment to remove debris. The spermatozoa-to-oocyte ratio was 100:1, following the same procedure described in Tallec et al. (2018). After $48 \mathrm{~h}$, the beakers were sieved at $40 \mu \mathrm{m}$ to collect larvae, and samples were fixed with a formaldehyde-seawater solution $(0.1 \%$ final $)$ to estimate the D- 
larval yield by light microscopy (Zeiss Axio Observer Z1; ×10-63 magnification). The D-larval yield was defined as: (number of normal D-larvae / number of oocytes) $\times 100$ (Song et al. 2009). Abnormal D-larvae referred to shell/mantle malformations and developmental arrests (Mottier et al. 2013).

\section{Statistical analyses and graphical representations}

Statistical analyses and graphical representations were conducted using the R Software (R Core Team, 2016). All data were screened for normality (Shapiro-Wilk test) and homoscedasticity (Levene test). Percentages were analyzed after angular transformations, except for the percentage of motile spermatozoa, which was subjected to a fourth-root transformation to respect statistical rules. Particle behavior was compared between the experimental media (EM) and FSW with the t-test method. Motility, flow cytometry analyses, and lipid classes among treatments were analyzed by one-way ANOVA or the Kruskall-Wallis test, followed by pairwise comparison (Tukey's post hoc or Conover's post hoc test for parametric or nonparametric analyses, respectively). Modifications of FA composition in the polar and neutral fractions were identified by one-way analysis of similarities (ANOSIM) using a Bray-Curtis similarity matrix to separate clusters $(R=1$ : perfect separation; $R=0.5$ : satisfactory separation, $\mathrm{R}=0$ : poor separation cluster) (Long et al. 2018). Correlations were made with the Pearson's method between the percentage of motile spermatozoa or VAP and the D-larval yield. The significance threshold of the statistical analyses was fixed at 0.05 . Data were expressed as the means \pm standard deviation (SD).

\section{Results}

\section{Characterization of nanopolystyrene beads in seminal media}

The commercial size $(50 \mathrm{~nm})$ of both $50-\mathrm{NH}_{2}$ and $50-\mathrm{COOH}$ beads was verified by TEM (Figure S1). In the experimental medium (EM), the $50-\mathrm{NH}_{2}$ suspension showed a size of 100.2 $\pm 2.0 \mathrm{~nm}$ and $\zeta$-potential of $14.7 \pm 3.2 \mathrm{mV}$ (Figures $1 \mathrm{~A}$ and $1 \mathrm{~B}$ ). The $50-\mathrm{COOH}$ suspension formed microscale aggregates characterized by a size of 7,435 $\pm 538 \mathrm{~nm}$ and a $\zeta$-potential of $12.5 \pm 1.5 \mathrm{mV}$ (Figures 1C and 1D). The size of the 50-COOH suspension increased significantly by 2.3 -fold in EM ( $\mathrm{df}=3.5$, p-value $=0.002$ ) compared with FSW (data from Tallec et al., 2018).

[Figure 1 near here] 


\section{Effects on spermatozoa motility}

Compared with the control treatment, both $50-\mathrm{NH}_{2}$ and $50-\mathrm{COOH}$ beads significantly altered spermatozoa motility (Figure 2). At 10 and $25 \mu \mathrm{g} \cdot \mathrm{mL}^{-1}, 50-\mathrm{NH}_{2}$ beads significantly reduced the percentage of motile spermatozoa (-79 and $-99 \%$, respectively; F-value $=28.18$, p-values < 0.001 ) and the VAP (-62 and -94\%, respectively; Kruskal-Wallis chi-squared $=21.75$, p-values $<0.001$ ) (Figures 2A and 2B). Exposures to 50-COOH beads only caused a significant effect at the highest concentration $\left(25 \mu \mathrm{g} \cdot \mathrm{mL}^{-1}\right)$ with reductions of the percentage of motile spermatozoa $(-66 \%$; F-value $=13.18$, p-value $<0.001)$ and the $\operatorname{VAP}(-38 \%$; F-value $=5.22$ pvalue $=0.01)($ Figures $2 \mathrm{C}$ and $2 \mathrm{D})$.

\section{[Figure 2 near here]}

\section{Morphology and functional characteristics of spermatozoa exposed to nano-PS}

The relative size and complexity (FSC and SSC, respectively) of the spermatozoa were not affected (p-values > 0.05) by exposures to $50-\mathrm{NH}_{2}$ beads (Table 1). The FSC was not statistically different among all concentrations of 50-COOH beads (p-value >0.05). At 10 and $25 \mu \mathrm{g} \cdot \mathrm{mL}^{-1}$ of $50-\mathrm{COOH}$ beads, the SSC increased significantly (+19\% and 33\%, respectively; F-value $=20.77$, p-values $=0.005$ and $<0.001$, respectively) compared with the control treatment. The functional characteristics of spermatozoa (percentage of live cells, acrosomal integrity and ROS production) were not significantly altered (p-values $>0.05$ ) by exposures to $50-\mathrm{NH}_{2}$ and 50-COOH beads at any concentration (Table 1).

\section{[Table 1 near here]}

\section{Lipid composition of spermatozoa exposed to nano-PS}

Neither type of nano-PS beads affected the total lipid content (mean value $=3.99 \pm 0.17 \mathrm{mg} .10^{9}$ spermatozoa $^{-1}$; $\mathrm{p}$-value $>0.05$; Table 2). The overall percentages of membrane lipids (mean value $=98.23 \% \pm 0.03 \%$ ) and storage lipids (mean value $=1.77 \% \pm 0.03 \%$ ) were statistically similar ( $\mathrm{p}$-values > 0.05) among all treatments. Statistical analyses revealed a significantly higher relative proportion $(+11.5 \%$; F-value $=19.09$, $\mathrm{p}$-value $=0.003)$ of phosphatidylserine at the highest concentration $\left(25 \mu \mathrm{g} \cdot \mathrm{mL}^{-1}\right)$ of $50-\mathrm{NH}_{2}$ beads in comparison to other treatments including control. Other class proportions remained unchanged among all treatments (p-values $>0.05$ ) (Table 2). No changes were observed in the PC/PE ratio (mean value $=1.58 \pm 0.02 ; \mathrm{p}$ - 
value > 0.05). One-way analysis of similarities (ANOSIM) revealed no statistical differences in the FA composition among treatments, for either the NL $(R=-0.2$ and p-value $>0.05$; Table $\mathrm{S} 1)$ or PL $(\mathrm{R}=0.18$ and $\mathrm{p}$-value $>0.05$; Table $\mathrm{S} 2)$.

[Table 2 near here]

\section{Interactions between nano-PS beads and spermatozoa}

Confocal laser scanning microscopy observations revealed that the $50-\mathrm{NH}_{2}$ and $50-\mathrm{COOH}$ beads appeared to adhere to the external membrane of spermatozoa head (Figures 3B, 3C and $3 \mathrm{D})$, notably on the acrosomal area. For the $50-\mathrm{COOH}$ beads treatment, spermatozoa were embedded in aggregates of 50-COOH beads (Figure 3E; Figure S2). This pattern of large aggregates containing trapped spermatozoa was not observed for the $50-\mathrm{NH}_{2}$ beads treatment. Adhesion of nano-PS beads to the spermatozoa was observed by both TEM and SEM, but only with the $50-\mathrm{NH}_{2}$ beads (Figures 4 and 5). No alterations of internal or external structures were remarked in spermatozoa exposed to either nano-PS beads when compared to the control treatment. Neither $50-\mathrm{NH}_{2}$ nor $50-\mathrm{COOH}$ beads were detected inside spermatozoa with the TEM observations and the orthogonal views obtained by confocal microscopy (Figures S3 and S4).

\section{[Figure 3 near here] \\ [Figure 4 near here] \\ [Figure 5 near here]}

\section{Effects on the reproductive success}

The 50- $\mathrm{NH}_{2}$ beads induced significant decreases in the D-larval yield at 10 and $25 \mu \mathrm{g} \cdot \mathrm{mL}^{-1}$ ($59 \%$ and $-95 \%$, respectively; F-value $=24.41$, p-value $=0.01$ and $<0.001$, respectively) (Figure 6A). By contrast, exposures to 50-COOH beads had no effects in the D-larval yield (p-value > 0.05: Figure $6 \mathrm{~B}$ ) compared with the control treatment. Significant positive correlations were found in response to $50-\mathrm{NH}_{2}$ beads exposures between: (i) the D-larval yield and spermatozoa motility (p-value $<0.001 ; R^{2}=0.68$; Figure 7A); (ii) the D-larval yield and VAP (p-value < $0.001 ; R^{2}=0.76 ;$ Figure 7B).

[Figure 6 near here]

[Figure 7 near here] 


\section{Discussion}

Adverse effects on oyster spermatozoa depend on nanoparticle type. Healthy spermatozoa are crucial for ensuring the sustainability of $C$. gigas through the transfer of genetic heritage to oocytes and offspring. Among the parameters that define the quality of spermatozoa, the motility (e.g., the percentage of motile spermatozoa and the swimming speed) and reproductive success are predominant (Taylor et al. 2014). Here, despite a very short exposure of $1 \mathrm{~h}$, the 50$\mathrm{NH}_{2}$ beads reduced the percentage of motile spermatozoa and their VAP, leading to a decrease in the D-larval yield, which was used as a proxy for reproductive success. While the present study showed that toxic effects on spermatozoa appeared from $10 \mu \mathrm{g} \cdot \mathrm{mL}^{-1}$ of $50-\mathrm{NH}_{2}$ beads, embryotoxicity was observed from $0.1 \mu \mathrm{g} \cdot \mathrm{mL}^{-1}$ in oyster embryos exposed to the same particles (Tallec et al. 2018). Higher embryotoxicity than spermiotoxicity has been previously observed in oysters and sea urchins embryos/spermatozoa exposed to PAH-contaminated sediments and xenobiotics (Geffard et al. 2001, Manzo et al. 2006). This difference can be related to the set of intense metabolic and morphological modifications (e.g., numerous cleavages, gastrulation, organogenesis, shell calcification) triggered during embryogenesis (Fitzpatrick et al. 2008).

By contrast, the 50-COOH beads seem to have only a transitory effect on oyster spermatozoa, i.e., a decrease in the motility at the highest concentration, without negative outcomes for their reproductive success as suggested by the similar D-larval yield among conditions derived from control or exposed spermatozoa. These observations suggest an involvement of different toxic pathways between $50-\mathrm{NH}_{2}$ and $50-\mathrm{COOH}$ beads on oyster spermatozoa, in agreement with previous studies (Della Torre et al. 2014, Manfra et al. 2017, Tallec et al. 2018). For instance, the $50-\mathrm{NH}_{2}$ beads caused a strong decrease in the embryogenesis success of the oyster C. gigas $\left(\mathrm{EC}_{50}=0.15 \mu \mathrm{g} \cdot \mathrm{mL}^{-1}\right)$, the sea urchin Paracentrotus lividus $\left(\mathrm{EC}_{50}=2.61 \mu \mathrm{g} \cdot \mathrm{mL}^{-1}\right)$ and the survival of the rotifer Brachionus plicatilis $\left(\mathrm{EC}_{50}=6.62 \mu \mathrm{g} \cdot \mathrm{mL}^{-1}\right)$ whereas 50-COOH beads had a lower toxicity $\left(\mathrm{EC}_{50}=11.60 \mu \mathrm{g} \cdot \mathrm{mL}^{-1}\right.$ for the embryogenesis success of $C$. gigas $)$ or no effect (survival of B. plicatilis, embryogenesis of P. lividus). In the one hand, the aggregation of 50$\mathrm{COOH}$ beads in the experimental medium decreases the surface-to-volume ratio of the particle suspension, decreasing particle reactivity and therefore toxic effects on cells in comparison to $50-\mathrm{NH}_{2}$ that remained unaggregated in seawater. On the other hand, the fluctuating toxicity between $50-\mathrm{NH}_{2}$ and $50-\mathrm{COOH}$ beads is also linked to the surface properties of the nanoparticles (e.g., surface charge), which are key-factors affecting the behavior and interactions with biological membrane (Cho et al. 2009, Nangia and Sureshkumar 2012, Della 
Torre et al. 2014, Tallec et al. 2019). The positive charge of the $50-\mathrm{NH}_{2}$ beads in seawater favor interactions with cells, thereby increasing their toxic effects compared with the negativelycharged 50-COOH beads (Della Torre et al. 2014). The stronger interactions between 50- $\mathrm{NH}_{2}$ beads and membrane than 50-COOH beads could explain results of TEM and SEM for which only $50-\mathrm{NH}_{2}$ beads are found to attach on spermatozoa despite numerous cleaning steps performed during the sample preparation.

The two types of nanobeads used in the present study allowed to test effects of the surface charge and the behavior of particles on oyster spermatozoa. Although the $50-\mathrm{NH}_{2}$ beads are excellent model particles to study effect of nanoparticles on marine model owing to its high stability in seawater, it is expected that nanoplastics in environment have carboxylated surfaces due to the oxidation processes occurring in seawater (Fotopoulou and Karapanagioti, 2012). This combined to the effects of the 50- $\mathrm{COOH}$ beads observed on oyster spermatozoa only at the highest concentration, i.e. $25 \mu \mathrm{g} \cdot \mathrm{mL}^{-1}\left(3.6 \times 10^{11}\right.$ particles. $\left.\mathrm{mL}^{-1}\right)$, suggests a limited/negligible environmental risk of nanopolystyrene beads for this type of cell comparing to the highest concentrations of microplastics reported at sea (to our knowledge 8 particles.mL 1; Brandon et al., 2020) even if the nanoplastic concentrations in ocean are expected to be higher than microplastics (Wagner and Reemtsma, 2019).

\section{The 50- $\mathrm{NH}_{2}$ beads toxicity on oyster spermatozoa is not related to membrane breakage or} modification of cell defenses. Numerous studies have reported cytotoxicity (e.g., a decrease in cell viability, an increase of ROS production) in cell lines (e.g., macrophage, brain astrocytoma) and aquatic organisms (e.g., cyanobacteria) after exposures to $50-\mathrm{NH}_{2}$ beads at concentrations close to the ones used in the present study, signaling a perturbation of cell defenses (Xia et al. 2008, Bexiga et al. 2011, Feng et al. 2019). In oyster spermatozoa, no variations in ROS production or other markers of cytotoxicity (e.g., acrosomal integrity) were observed, despite a significant decrease in key sperm functions (motility and reproductive success) induced by 50$\mathrm{NH}_{2}$ beads. A similar pattern (i.e., a decrease in spermatozoa quality without overproduction of ROS) was previously described in bovine spermatozoa exposed to gold nanoparticles at 10 $\mu \mathrm{g} \cdot \mathrm{mL}^{-1}$ (Taylor et al. 2014). These authors suggested that membrane perturbations due to the attachment of gold nanoparticles could explain the decreases in motility and fertilization success. In this regard, one pathway for toxicity of nano-PS proposed in the literature is related to membrane disturbance (Rossi et al. 2014, Jeong et al. 2018, Feng et al. 2019). For instance, 50- $\mathrm{NH}_{2}$ beads at 2.5 and $4 \mu \mathrm{g} \cdot \mathrm{mL}^{-1}$ induced severe alterations in Synechococcus elongatus membrane (increase in permeability and loss of integrity) (Feng et al. 2019). The present 
experiment was therefore designed to test this hypothesis on oyster spermatozoa. Although flow cytometry analyses suggested no effects of the $50-\mathrm{NH}_{2}$ beads on spermatozoa membrane integrity, the increase in the phosphatidylserine relative level observed at $25 \mu \mathrm{g} \cdot \mathrm{mL}^{-1}(+11.5 \%)$ suggests a membrane reorganization in response to the adhesion of $50-\mathrm{NH}_{2}$ beads on spermatozoa membrane. As previously reported, marine spermatozoa can reorganize the lipid bilayer under homeostasis damages (e.g. osmotic stress) (Cosson, 2004). Nanomaterials can interact with membrane compounds such as ion channels, modifying ion homeostasis and leading to physiological disruptions (Yin et al., 2019). For instance, a perturbation of the transmembrane $\mathrm{Na}^{+} / \mathrm{K}^{+}$-ATPases and $\mathrm{Ca}^{2+}$-ATPases was suggested as cause of the loss of motility in bovine spermatozoa displaying gold nanoparticle attachments (Taylor et al. 2014). As phosphatidylserine participates actively in the stability of essential transmembrane components such as $\mathrm{Na}^{+} / \mathrm{K}^{+}$-ATPases (Wheeler and Whittam, 1970), we hypothesize that the increase in the phosphatidylserine relative level could reflect a cellular response to handle effect of $50-\mathrm{NH}_{2}$ beads on ion channels such as conformational changes. Nevertheless, it seemed that this membrane reorganization was not sufficient to maintain cell motility. Therefore, further functional work is needed to establish effects of $50-\mathrm{NH}_{2}$ beads in the membrane organization and understand precisely the origin and the consequences of the relative increase of phosphatidylserine.

Aggregates of 50-COOH beads could trap oyster spermatozoa. Interestingly, the 50-COOH suspension displayed a higher aggregate size (2.3 times) in the experimental medium compared with seawater. The contribution of the high cations content $\left(\mathrm{Na}^{+}, \mathrm{Ca}^{2+}\right.$, and $\left.\mathrm{K}^{+}\right)$occurring naturally in the seminal fluid (Boulais et al. 2018) may have promoted interactions with the negative surface charge of the 50- $\mathrm{COOH}$ beads, thereby increasing homo-aggregation processes. Under these conditions, spermatozoa interact with microscale aggregates that could affect their movement. Indeed, confocal microscopy and SEM showed a myriad of spermatozoa trapped within large microscale aggregates formed by the 50-COOH beads in the experimental medium. This result suggests a physical entrapment of spermatozoa by $50-\mathrm{COOH}$ aggregates and could explain the decrease in spermatozoa motility at the highest dose. This mechanism was previously suggested for coral spermatozoa when exposed to colloidal matter (suspended sediments) that formed aggregates (Humanes et al. 2017). The lack of an observed effect on Dlarval yield may be an effect arising from dilution of the spermatozoa at the end of the exposure in $1.5 \mathrm{~L}$ to evaluate the reproductive success. This step could have liberated spermatozoa trapped in aggregates, thereby allowing a normal fertilization rate and thus no effect on the D- 
larval yield. This also suggests there was no cell damage from the exposure, which is consistent with the other results, i.e., no effects on membrane (composition, integrity) and on the ROS production. However, we cannot exclude a total absence of sperm health impairments as the high spermatozoa-to-oocyte ratio (100:1) can interfere in the result of the D-larval yield. Overall, millions of spermatozoa are produced/released but at the end, one is enough to deliver genetic material in oocyte. Therefore, the fraction of unaffected spermatozoa by $50-\mathrm{COOH}$ aggregates could be sufficient to ensure fertilization.

No translocation of nano-PS beads into oyster spermatozoa. Conventionally, the risk of translocation into cells depends on the size of particles; e.g., translocation efficiency of nanoPS beads into human cell lines is up to $7.8 \%$ for $50 \mathrm{~nm}$ beads and $0.8 \%$ for $100 \mathrm{~nm}$ beads (Walczak et al. 2015). Here, no evidence of translocation was highlighted in oyster spermatozoa by either confocal and electron microscopy for either $50-\mathrm{NH}_{2}$ or $50-\mathrm{COOH}$ beads at $25 \mu \mathrm{g} \cdot \mathrm{mL}^{-}$ ${ }^{1}$. This result could be explained by specific properties of the germ cells, i.e., spermatozoa do not have endocytic processes, which are important pathways for internalizing nanoparticles (Taylor et al. 2015). Nevertheless, because (i) other studies have reported translocation of engineered nanoparticles into spermatozoa, e.g. $40 \mathrm{~nm}$ silver nanoparticles in mouse spermatozoa (Yoisungnern et al. 2015), (ii) nano-PS beads have low contrast for TEM analyses (also noted by Jeong et al. (2018)), a relevant follow-up study would be to expose oyster spermatozoa to ${ }^{14} \mathrm{C}$-radiolabeled or metal-doped nano-PS which may greatly enhance nanoparticles detection and fate in marine cells and organisms (Al-Sid-Cheikh et al. 2018, Mitrano et al. 2019).

\section{Conclusion}

This study demonstrated interactions between nano-PS beads and oyster spermatozoa with spermiotoxicity as a function of the surface functionalization. Several cellular disruptions and possibly translocation were expected, but only a toxicity related to the adhesion of nano-PS beads on the spermatozoa was observed. This finding calls for further analyses on transmembrane components, such as recognition proteins or ion channels, to establish the toxicity pathway.

Although this study highlighted effects of nano-PS particles on oyster spermatozoa, we remain cautious about any extrapolation to the natural environment. Firstly, we used model nanoparticles with spherical shape and surface functionalization available commercially, 
whereas environmental nanoplastics could be more complex in terms of both shape (e.g., irregular) and surface chemistry (e.g., presence of pollutants, eco-corona) (Paul-Pont et al., 2018). This complexity must be considered in future studies using oyster spermatozoa as a sensitive model. From a toxicological point of view it would be interesting in future works to test other nanomaterials possessing $-\mathrm{NH}_{2}$ or $-\mathrm{COOH}$ functionalizations to verify if the toxicity is only due to the surface properties without implications of the core material. Secondly, we used dose-response experiments to determine the effect concentration of nano-PS beads because the concentration of nanoplastics in ocean is currently unavailable due to methodological gaps. Toxic effects were observed at extremely high concentrations, suggesting a very limited risk to oyster spermatozoa in the natural environment. Due to the lack of environmental data on such small particles, our results will have to be confronted in the future with data obtained in the field for the nanoplastic compartment. Therefore, the characterization and quantification of environmental nanoplastics, as well as the production of model particles that better mimic natural nanoplastics, are required to provide accurate risks scenarios and to determine the extent to which these nanoplastic contaminants constitute a threat for marine ecosystems.

\section{Acknowledgements}

This study was supported by the ANR-Nanoplastics project (ANR-15-CE34-0006). K. Tallec has a French doctoral grant from the "Région Bretagne" (50\%) and Ifremer (50\%). The authors thank E. Fleury, M. Suquet, J.L. Seugnet and the staff of the experimental station of Argenton for their technical assisstance. We thank A. Donval for TEM preparation, V. Foulon, N. Gayet and the Imaging Platform of UBO (Plateforme d'imagerie et de Mesures en Microscopie [PIMM]) for the help with microscopy analyses. We thank H. McCombie for her help in editing the English.

\section{Disclosure Statement}

The authors report no conflict of interest.

\section{References}

Al-Sid-Cheikh, M., Rowland, S.J., Stevenson, K., Rouleau, C., Henry, T.B., and Thompson, R.C., 2018. Uptake, whole-body distribution \& depuration of nanoplastics by the scallop Pecten maximus, at environmentally realistic concentrations. Environmental Science \& Technology, $52,14480-14486$. 
Balbi, T., Camisassi, G., Montagna, M., Fabbri, R., Franzellitti, S., Carbone, C., Dawson, K., and Canesi, L., 2017. Impact of cationic polystyrene nanoparticles (PS- $\left.\mathrm{NH}_{2}\right)$ on early embryo development of Mytilus galloprovincialis : Effects on shell formation. Chemosphere, 186, 1-9.

Bayne, B., 2017. Biology of Oysters. Academic Press, 862 p.

Bergmann, M., Wirzberger, V., Krumpen, T., Lorenz, C., Primpke, S., Tekman, M.B., and Gerdts, G., 2017. High quantities of microplastic in Arctic deep-sea sediments from the HAUSGARTEN observatory. Environmental Science \& Technology, 51, 11000-11010.

Bexiga, M.G., Varela, J. A., Wang, F., Fenaroli, F., Salvati, A., Lynch, I., Simpson, J.C., and Dawson, K. A., 2011. Cationic nanoparticles induce caspase 3-, 7- and 9-mediated cytotoxicity in a human astrocytoma cell line. Nanotoxicology, 5 (4), 557-567.

Boulais, M., Suquet, M., Arsenault-Pernet, E.J., Malo, F., Queau, I., Pignet, P., Ratiskol, D., Le Grand, J., Huber, M., and Cosson, J., 2018. pH controls spermatozoa motility in the Pacific oyster (Crassostrea gigas). Biology Open, 7 (3), bio031427.

Boulais, M., Soudant, P., Le Goïc, N., Quéré, C., Boudry, P., and Suquet, M., 2015. Involvement of Mitochondrial Activity and OXPHOS in ATP Synthesis During the Motility Phase of Spermatozoa in the Pacific Oyster, Crassostrea gigas. Biology of Reproduction, 93 (5), 1-7.

Brandon, J.A., Freibott, A., and Sala, L.M., 2020. Patterns of suspended and salp-ingested microplastic debris in the North Pacific investigated with epifluorescence microscopy. Limnology and Oceanography Letters, 5 (1), 46-53.

Catarino, A.I., Frutos, A., and Henry, T.B., 2019. Use of fluorescent-labelled nanoplastics (NPs) to demonstrate NP absorption is inconclusive without adequate controls. Science of The Total Environment, 670, 915-920.

Cho, E.C., Xie, J., Wurm, P.A., and Xia, Y., 2009. Understanding the role of surface charges in cellular adsorption versus internalization by selectively removing gold nanoparticles on the cell surface with a I2/KI etchant. Nano Letters, 9 (3), 1080-1084.

Cosson, J., 2004. The Ionic and Osmotic Factors Controlling Motility of Fish Spermatozoa. Aquaculture International, 12 (1), 69-85.

Da Costa, F., Petton, B., Mingant, C., Bougaran, G., Rouxel, C., Quéré, C., Wikfors, G.H., Soudant, P., and Robert, R., 2016. Influence of one selected Tisochrysis lutea strain rich in 
lipids on Crassostrea gigas larval development and biochemical composition. Aquaculture Nutrition, 22 (4), 813-836.

Di Poi, C., Evariste, L., Serpentini, A., Halm-Lemeille, M.P., Lebel, J.M., and Costil, K., 2014. Toxicity of five antidepressant drugs on embryo-larval development and metamorphosis success in the Pacific oyster, Crassostrea gigas. Environmental Science and Pollution Research, 21 (23), 13302-13314.

Eriksen, M., Lebreton, L.C.M., Carson, H.S., Thiel, M., Moore, C.J., Borerro, J.C., Galgani, F., Ryan, P.G., and Reisser, J., 2014. Plastic Pollution in the World's Oceans: More than 5 Trillion Plastic Pieces Weighing over 250,000 Tons Afloat at Sea. PLoS ONE, 9 (12), 1-15.

Feng, L., Li, J.-W., Xu, E.G., Sun, X.-D., Zhu, F.-P., Ding, Z.-J., Tian, H.-Y., Dong, S.-S., Xia, P.-F., and Yuan, X.-Z., 2019. Short-term exposure of positively charged polystyrene nanoparticles causes oxidative stress and membrane destruction in cyanobacteria. Environmental Science: Nano.

Fitzpatrick, J.L., Nadella, S., Bucking, C., Balshine, S., and Wood, C.M., 2008. The relative sensitivity of sperm, eggs and embryos to copper in the blue mussel (Mytilus trossulus). Comparative Biochemistry and Physiology Part C: Toxicology \& Pharmacology, 147 (4), 441449.

Folch, J., Lees, M., and Stanley, G.H.S., 1957. A simple method for the isolation and purification of total lipides from animal tissues. Journal of Biological Chemistry, 226, 497-509.

Fotopoulou, K.N. and Karapanagioti, H.K., 2012. Surface properties of beached plastic pellets. Marine Environmental Research, 81, 70-77.

Galgani, F., Hanke, G., Werner, S., and De Vrees, L., 2013. Marine litter within the European Marine Strategy Framework Directive. ICES Journal of Marine Science, 70 (6), 1055-1064.

Gallo, A., Manfra, L., Boni, R., Rotini, A., Migliore, L., and Tosti, E., 2018. Cytotoxicity and genotoxicity of $\mathrm{CuO}$ nanoparticles in sea urchin spermatozoa through oxidative stress. Environment International, 118, 325-333.

Gallo, A. and Tosti, E., 2019. Effects of ecosystem stress on reproduction and development. Molecular Reproduction and Development, 1-4.

Garner, D.L. and Johnson, L.A., 1995. Viability Assessment of Mammalian Sperm Using SYBR-14 and Propidium Iodide 1. Biology of Reproduction, 53 (2), 276-284. 
Geffard, O., Budzinski, H., Augagneur, S., Seaman, M.N.L., and His, E., 2001. Assessment of sediment contamination by spermiotoxicity and embryotoxicity bioassays with sea urchins (Paracentrotus lividus) and oysters (Crassostrea gigas). Environmental Toxicology and Chemistry, 20 (7), 1605-1611.

GESAMP (2015). "Sources, fate and effects of microplastics in the marine environment: a global assessment” (Kershaw, P. J., ed.). (IMO/FAO/UNESCOIOC/UNIDO/WMO/IAEA/UN/UNEP/UNDP Joint Group of Experts on the Scientific Aspects of Marine Environmental Protection). Rep. Stud. GESAMP No. 90, 96 p..

Gigault, J., Ter Halle, A., Baudrimont, M., Pascal, P., Gauffre, F., Phi, T.-L., El Hadri, H., Grassl, B., and Reynaud, S., 2018. Current opinion: What is a nanoplastic? Environmental Pollution, 235, 1030-1034.

González-Fernández, C., Tallec, K., Le Goïc, N., Lambert, C., Soudant, P., Huvet, A., Suquet, M., Berchel, M., and Paul-Pont, I., 2018. Cellular responses of Pacific oyster (Crassostrea gigas) gametes exposed in vitro to polystyrene nanoparticles. Chemosphere, 208, 764-772.

Grabowski, J.H., Brumbaugh, R.D., Conrad, R.F., Keeler, A.G., Opaluch, J.J., Peterson, C.H., Piehler, M.F., Powers, S.P., and Smyth, A.R., 2012. Economic Valuation of Ecosystem Services Provided by Oyster Reefs. BioScience, 62 (10), 900-909.

Hartmann, N., Hüffer, T., Thompson, R.C., Hassellöv, M., Verschoor, A., Daugaard, A.E., Rist, S., Karlsson, T.M., Brennholt, N., Cole, M., Herrling, M.P., Heß, M., Ivleva, N.P., Lusher, A.L., and Wagner, M., 2019. Are we speaking the same language? Recommendations for a definition and categorization framework for plastic debris. Environmental Science \& Technology, 53, 1039-1047.

Hernandez, L.M., Yousefi, N., and Tufenkji, N., 2017. Are There Nanoplastics in Your Personal Care Products? Environmental Science \& Technology Letters, 4 (7), 280-285.

Humanes, A., Ricardo, G.F., Willis, B.L., Fabricius, K.E., and Negri, A.P., 2017. Cumulative effects of suspended sediments, organic nutrients and temperature stress on early life history stages of the coral Acropora tenuis. Scientific Reports, 7 (November 2016), 1-11.

Hutchinson, T.H., Solbé, J., and Kloepper-Sams, P.J., 1998. Analysis of the ECETOC Aquatic Toxicity (EAT) database. III - Comparative toxicity of chemical substances to different life stages of aquatic organisms. Chemosphere, 36 (1), 129-142. 
Huvet, A., Paul-Pont, I., Fabioux, C., Lambert, C., Suquet, M., Thomas, Y., Robbens, J., Soudant, P., and Sussarellu, R., 2016. Reply to Lenz et al.: Quantifying the smallest microplastics is the challenge for a comprehensive view of their environmental impacts. Proceedings of the National Academy of Sciences, 113 (29), E4123-E4124.

Jahnke, A., Arp, H.P.H., Escher, B.I., Gewert, B., Gorokhova, E., Kühnel, D., Ogonowski, M., Potthoff, A., Rummel, C., Schmitt-Jansen, M., Toorman, E., and MacLeod, M., 2017. Reducing Uncertainty and Confronting Ignorance about the Possible Impacts of Weathering Plastic in the Marine Environment. Environmental Science \& Technology Letters, 4 (3), 85-90.

Jambeck, J.R., Geyer, R., Wilcox, C., Siegler, T.R., Perryman, M., Andrady, A., Narayan, R., and Law, K.L., 2015. Plastic waste inputs from land into the ocean. Science, 347 (6223), 768 771.

Jeong, C.-B., Kang, H.-M., Lee, Y.H., Kim, M.-S., Lee, J.-S., Seo, J.S., Wang, M., and Lee, J.S., 2018. Nanoplastic Ingestion Enhances Toxicity of Persistent Organic Pollutants (POPs) in the Monogonont Rotifer Brachionus koreanus via Multixenobiotic Resistance (MXR) Disruption. Environmental Science \& Technology, 52, 11411-11418.

Jeong, C.B., Kang, H.M., Lee, M.C., Kim, D.H., Han, J., Hwang, D.S., Souissi, S., Lee, S.J., Shin, K.H., Park, H.G., and Lee, J.S., 2017. Adverse effects of microplastics and oxidative stress-induced MAPK/Nrf2 pathway-mediated defense mechanisms in the marine copepod Paracyclopina nana. Scientific Reports, 7, 1-11.

Jeong, C.B., Won, E.J., Kang, H.M., Lee, M.C., Hwang, D.S., Hwang, U.K., Zhou, B., Souissi, S., Lee, S.J., and Lee, J.S., 2016. Microplastic Size-Dependent Toxicity, Oxidative Stress Induction, and p-JNK and p-p38 Activation in the Monogonont Rotifer (Brachionus koreanus). Environmental Science \& Technology, 50 (16), 8849-8857.

Kadar, E., Tarran, G.A., Jha, A.N., and Al-Subiai, S.N., 2011. Stabilization of engineered zerovalent nano-iron with Na-acrylic copolymer enhances spermiotoxicity. Environmental Science \& Technology, 45 (8), 3245-3251.

Koelmans, A.A., Besseling, E., and Shim, W.J., 2015. Nanoplastics in the Aquatic Environment. Critical Review. In: Marine Anthropogenic Litter. Cham: Springer International Publishing, 325-340. 
Lambert, C., Soudant, P., Choquet, G., and Paillard, C., 2003. Measurement of Crassostrea gigas hemocyte oxidative metabolism by flow cytometry and the inhibiting capacity of pathogenic vibrios. Fish \& Shellfish Immunology, 15 (3), 225-240.

Lee, K., Shim, W.J., Kwon, O.Y., and Kang, J., 2013. Size-Dependent Effects of Micro Polystyrene Particles in the Marine Copepod Tigriopus japonicus. Environmental Science \& Technology, 47 (19), 11278-11283.

Lewis, C. and Ford, A.T., 2012. Infertility in male aquatic invertebrates: A review. Aquatic Toxicology, 120-121, 79-89.

Le Goïc, N., Hégaret, H., Fabioux, C., Miner, P., Suquet, M., Lambert, C., and Soudant, P., 2013. Impact of the toxic dinoflagellate Alexandrium catenella on Pacific oyster reproductive output: application of flow cytometry assays on spermatozoa. Aquatic Living Resources, 26 (3), 221-228.

Le Grand, F., Soudant, P., Siah, A., Tremblay, R., Marty, Y., and Kraffe, E., 2014. Disseminated neoplasia in the soft-shell clam Mya arenaria: Membrane lipid composition and functional parameters of circulating cells. Lipids, 49 (8), 807-818.

Li, Z., Agellon, L.B., Allen, T.M., Umeda, M., Jewell, L., Mason, A., and Vance, D.E., 2006. The ratio of phosphatidylcholine to phosphatidylethanolamine influences membrane integrity and steatohepatitis. Cell Metabolism, 3 (5), 321-331.

Long, M., Tallec, K., Soudant, P., Le Grand, F., Donval, A., Lambert, C., Sarthou, G., Jolley, D.F., and Hégaret, H., 2018. Allelochemicals from Alexandrium minutum induce rapid inhibition of metabolism and modify the membranes from Chaetoceros muelleri. Algal Research, 35, 508-518.

Lorenz, C., Roscher, L., Meyer, M.S., Hildebrandt, L., Prume, J., Löder, M.G.J., Primpke, S., and Gerdts, G., 2019. Spatial distribution of microplastics in sediments and surface waters of the southern North Sea. Environmental Pollution, 252, 1719-1729.

Mai, H., Cachot, J., Clérandeau, C., Martin, C., Mazzela, N., Gonzalez, P., and Morin, B., 2018. An environmentally realistic pesticide and copper mixture impacts embryonic development and DNA integrity of the Pacific oyster, Crassostrea gigas. Environmental Science and Pollution Research, 1-12. 
Manfra, L., Rotini, A., Bergami, E., Grassi, G., Faleri, C., and Corsi, I., 2017. Comparative ecotoxicity of polystyrene nanoparticles in natural seawater and reconstituted seawater using the rotifer Brachionus plicatilis. Ecotoxicology and Environmental Safety, 145, 557-563.

Manzo, S., Buono, S., and Cremisini, C., 2006. Toxic effects of Irgarol and Diuron on sea urchin Paracentrotus lividus early development, fertilization, and offspring quality. Archives of Environmental Contamination and Toxicology, 51 (1), 61-68.

Mattsson, K., Hansson, L.-A., and Cedervall, T., 2015. Nano-plastics in the aquatic environment. Environmental Science: Processes \& Impacts, 17 (10), 1712-1721.

Mintenig, S.M., Bäuerlein, P.S., Koelmans, A.A., Dekker, S.C., and Van Wezel, A.P., 2018. Closing the gap between small and smaller: towards a framework to analyse nano- and microplastics in aqueous environmental samples. Environmental Science: Nano, 5 (7), 16401649.

Mitrano, D.M., Beltzung, A., Frehland, S., Schmiedgruber, M., Cingolani, A., and Schmidt, F., 2019. Synthesis of metal-doped nanoplastics and their utility to investigate fate and behaviour in complex environmental systems. Nature Nanotechnology, 14 (4), 362-368.

Mottier, A., Kientz-Bouchart, V., Serpentini, A., Lebel, J.M., Jha, A.N., and Costil, K., 2013. Effects of glyphosate-based herbicides on embryo-larval development and metamorphosis in the Pacific oyster, Crassostrea gigas. Aquatic Toxicology, 128-129, 67-78.

Moutel, B., Gonçalves, O., Le Grand, F., Long, M., Soudant, P., Legrand, J., Grizeau, D., and Pruvost, J., 2016. Development of a screening procedure for the characterization of Botryococcus braunii strains for biofuel application. Process Biochemistry, 51 (11), 18551865 .

Nangia, S. and Sureshkumar, R., 2012. Effects of Nanoparticle Charge and Shape Anisotropy on Translocation through Cell Membranes. Langmuir, 28 (51), 17666-17671.

Paul-Pont, I., Tallec, K., Gonzalez-Fernandez, C., Lambert, C., Vincent, D., Mazurais, D., Zambonino-Infante, J.-L., Brotons, G., Lagarde, F., Fabioux, C., Soudant, P., and Huvet, A., 2018. Constraints and Priorities for Conducting Experimental Exposures of Marine Organisms to Microplastics. Frontiers in Marine Science, 5, 1-22. 
Peeken, I., Primpke, S., Beyer, B., Gütermann, J., Katlein, C., Krumpen, T., Bergmann, M., Hehemann, L., and Gerdts, G., 2018. Arctic sea ice is an important temporal sink and means of transport for microplastic. Nature Communications, 9 (1), 1505.

Pikuda, O., Xu, E.G., Berk, D., and Tufenkji, N., 2018. Toxicity Assessments of Micro- and Nanoplastics Can Be Confounded by Preservatives in Commercial Formulations. Environmental Science \& Technology Letters, 6, 21-25 .

PlasticsEurope, 2018. Plastics - the Facts 2018.

R Core Team (2016). R: A language and environment for statistical computing. R Foundation for Statistical Computing, Vienna, Austria. URL https://www.R-project.org/.

Reinhardt, K., Dobler, R., and Abbott, J., 2015. An Ecology of Sperm: Sperm Diversification by Natural Selection. Annual Review of Ecology, Evolution, and Systematics, 46 (1), 435-459.

Ringwood, A.H., McCarthy, M., Bates, T.C., and Carroll, D.L., 2010. The effects of silver nanoparticles on oyster embryos. Marine Environmental Research, 69, S49-S51.

Rossi, G., Barnoud, J., and Monticelli, L., 2014. Polystyrene nanoparticles perturb lipid membranes. Journal of Physical Chemistry Letters, 5 (1), 241-246.

Schür, C., Rist, S., Baun, A., Mayer, P., Hartmann, N.B., and Wagner, M., 2019. When Fluorescence is not a particle: The tissue translocation of microplastics in Daphnia magna seems an artifact. Environmental Toxicology and Chemistry, 38 (7), 1495-1503.

Schwaferts, C., Niessner, R., Elsner, M., and Ivleva, N.P., 2019. Methods for the analysis of submicrometer- and nanoplastic particles in the environment. TrAC Trends in Analytical Chemistry, 112, 52-65.

Song, Y.P., Suquet, M., Quéau, I., and Lebrun, L., 2009. Setting of a procedure for experimental fertilisation of Pacific oyster (Crassostrea gigas) oocytes. Aquaculture, 287 (3-4), 311-314.

Steele, S. and Mulcahy, M.F., 1999. Gametogenesis of the oyster Crassostrea gigas in southern Ireland. Journal of the Marine Biological Association of the UK, 79, 673-686.

Tallec, K., Blard, O., González-Fernández, C., Brotons, G., Berchel, M., Soudant, P., Huvet, A., and Paul-Pont, I., 2019. Surface functionalization determines behavior of nanoplastic solutions in model aquatic environments. Chemosphere, 225, 639-646. 
Tallec, K., Huvet, A., Di Poi, C., González-Fernández, C., Lambert, C., Petton, B., Le Goïc, N., Berchel, M., Soudant, P., and Paul-Pont, I., 2018. Nanoplastics impaired oyster free living stages, gametes and embryos. Environmental Pollution, 242, 1226-1235.

Taylor, U., Barchanski, A., Petersen, S., Kues, W.A., Baulain, U., Gamrad, L., Sajti, L., Barcikowski, S., and Rath, D., 2014. Gold nanoparticles interfere with sperm functionality by membrane adsorption without penetration. Nanotoxicology, 8, 118-127.

Taylor, U., Tiedemann, D., Rehbock, C., Kues, W.A., Barcikowski, S., and Rath, D., 2015. Influence of gold, silver and gold-silver alloy nanoparticles on germ cell function and embryo development. Beilstein Journal of Nanotechnology, 6 (1), 651-664.

Della Torre, C., Bergami, E., Salvati, A., Faleri, C., Cirino, P., Dawson, K.A., and Corsi, I., 2014. Accumulation and Embryotoxicity of Polystyrene Nanoparticles at Early Stage of Development of Sea Urchin Embryos Paracentrotus lividus. Environmental Science \& Technology, 48 (20), 12302-12311.

Vignier, J., Volety, A.K., Rolton, A., Le Goïc, N., Chu, F.L.E., Robert, R., and Soudant, P., 2017. Sensitivity of eastern oyster (Crassostrea virginica) spermatozoa and oocytes to dispersed oil: Cellular responses and impacts on fertilization and embryogenesis. Environmental Pollution, 225, 270-282.

Volety, A., Boulais, M., Donaghy, L., Vignier, J., Loh, A.N., and Soudant, P., 2016. Application of Flow Cytometry to Assess Deepwater Horizon Oil Toxicity on the Eastern Oyster Crassostrea virginica Spermatozoa. Journal of Shellfish Research, 35 (1), 91-99.

Wagner, S. and Reemtsma, T., 2019. Things we know and don't know about nanoplastic in the environment. Nature Nanotechnology, 14 (4), 300-301.

Walczak, A.P., Kramer, E., Hendriksen, P.J.M., Tromp, P., Helsper, J.P.F.G., van der Zande, M., Rietjens, I.M.C.M., and Bouwmeester, H., 2015. Translocation of differently sized and charged polystyrene nanoparticles in in vitro intestinal cell models of increasing complexity. Nanotoxicology, 9 (4), 453-461.

Wheeler, K. and Whittam, R., 1970. ATPase activity of the sodium pump needs phosphatidylserine. Nature, 225 (5231), 449-450. 
Wilson-Leedy, J.G. and Ingermann, R.L., 2007. Development of a novel CASA system based on open source software for characterization of zebrafish sperm motility parameters. Theriogenology, 67 (3), 661-672.

Wright, S.L. and Kelly, F.J., 2017. Plastic and Human Health: A Micro Issue? Environmental Science \& Technology, 51 (12), 6634-6647.

Xia, T., Kovochich, M., Liong, M., Zink, J.I., and Nel, A.E., 2008. Cationic Polystyrene Nanosphere Toxicity Depends on Cell-Specific Endocytic and Mitochondrial Injury Pathways. ACS Nano, 2 (1), 85-96.

Yin, S., Liu, J., Kang, Y., Lin, Y., Li, D., and Shao, L., 2019. Interactions of nanomaterials with ion channels and related mechanisms. British Journal of Pharmacology, 176 (19), 3754-3774.

Yoisungnern, T., Choi, Y.-J., Woong Han, J., Kang, M.-H., Das, J., Gurunathan, S., Kwon, D.N., Cho, S.-G., Park, C., Kyung Chang, W., Chang, B.-S., Parnpai, R., and Kim, J.-H., 2015. Internalization of silver nanoparticles into mouse spermatozoa results in poor fertilization and compromised embryo development. Scientific Reports, 5 (1), 11170.

Zhang, H., Kuo, Y.Y., Gerecke, A.C., and Wang, J., 2012. Co-release of hexabromocyclododecane (HBCD) and nano- and microparticles from thermal cutting of polystyrene foams. Environmental Science \& Technology, 46 (20), 10990-10996

\section{Table}

Table 1. Relative size (FSC; A.U.), relative complexity (SSC; A.U.), percentage of live cells (\%), ROS production (green fluorescence, A.U.), and acrosomal integrity (red fluorescence, A.U.) of oyster spermatozoa after $1 \mathrm{~h}$ of exposure to $50-\mathrm{NH}_{2}$ and $50-\mathrm{COOH}$ beads at five concentrations: 0 (Control), 0.1, 1, 10, and $25 \mu \mathrm{g} \cdot \mathrm{mL}^{-1}$. Data are given as means $\pm \mathrm{SD}(\mathrm{n}=6$ except for the acrosomal integrity, where $n=4)$. ANOVA was used to compare treatments with Tukey HSD for pairwise comparisons at the 5\% level; homogeneous groups share the same letter. NA = Not applicable as the acrosomal integrity was only assessed on control and treatments that affected the reproductive success was affected.

\begin{tabular}{|c|c|c|c|c|c|c|}
\hline Treatm & & $\begin{array}{c}\text { Relative Size } \\
\text { (FSC; A.U.) }\end{array}$ & $\begin{array}{c}\text { Relative } \\
\text { Complexity } \\
\text { (SSC; A.U.) }\end{array}$ & $\begin{array}{l}\text { Live cells } \\
(\%)\end{array}$ & $\begin{array}{c}\text { ROS } \\
\text { Production } \\
\text { (A.U.) }\end{array}$ & $\begin{array}{l}\text { Acrosomal } \\
\text { Integrity } \\
\text { (A.U.) }\end{array}$ \\
\hline \multicolumn{2}{|c|}{ Control } & $64.1 \pm 1.3^{\mathrm{a}}$ & $41.3 \pm 1.7^{\mathrm{a}}$ & $94.2 \pm 1.9^{\mathrm{a}}$ & $24.6 \pm 11.4^{\mathrm{a}}$ & $259.3 \pm 33.2^{a}$ \\
\hline $50-\mathrm{NH}_{2}$ & 0.1 & $64.1 \pm 1.4^{\mathrm{a}}$ & $40.8 \pm 1.5^{\mathrm{a}}$ & $95.5 \pm 2.5^{\mathrm{a}}$ & $22.6 \pm 8.6^{\mathrm{a}}$ & $N A$ \\
\hline
\end{tabular}




\begin{tabular}{c|cccccc}
1 & $64.5 \pm 1.3^{\mathrm{a}}$ & $42.5 \pm 1.6^{\mathrm{a}}$ & $95.2 \pm 1.8^{\mathrm{a}}$ & $25.4 \pm 10.8^{\mathrm{a}}$ & $N A$ \\
& 10 & $65.1 \pm 1.7^{\mathrm{a}}$ & $44.9 \pm 1.4^{\mathrm{a}}$ & $93.1 \pm 8.5^{\mathrm{a}}$ & $22.6 \pm 8.7^{\mathrm{a}}$ & $250.8 \pm 53.9^{\mathrm{a}}$ \\
& 25 & $64.6 \pm 0.7^{\mathrm{a}}$ & $40.6 \pm 3.1^{\mathrm{a}}$ & $97.4 \pm 1.6^{\mathrm{a}}$ & $19.3 \pm 8.2^{\mathrm{a}}$ & $297.8 \pm 14.9^{\mathrm{a}}$ \\
\hline \multirow{5}{*}{$50-\mathrm{COOH}$} & 0.1 & $64.5 \pm 1.2^{\mathrm{a}}$ & $41.6 \pm 2.2^{\mathrm{a}}$ & $95.1 \pm 2.1^{\mathrm{a}}$ & $20.0 \pm 4.3^{\mathrm{a}}$ & $N A$ \\
& 1 & $63.9 \pm 1.1^{\mathrm{a}}$ & $39.9 \pm 6.6^{\mathrm{a}}$ & $95.4 \pm 2.5^{\mathrm{a}}$ & $22.7 \pm 5.7^{\mathrm{a}}$ & $N A$ \\
& 10 & $64.7 \pm 0.9^{\mathrm{a}}$ & $49.5 \pm 1.8^{\mathrm{b}}$ & $95.7 \pm 2.4^{\mathrm{a}}$ & $20.4 \pm 4.8^{\mathrm{a}}$ & $N A$ \\
& 25 & $64.4 \pm 0.9^{\mathrm{a}}$ & $55.1 \pm 2.4^{\mathrm{b}}$ & $96.4 \pm 2.2^{\mathrm{a}}$ & $17.3 \pm 4.7^{\mathrm{a}}$ & $N A$ \\
\hline
\end{tabular}

Table 2. Total lipid content (mg.109 spermatozoa $^{-1}$ ) and lipid class composition of oyster spermatozoa after $1 \mathrm{~h}$ exposure to various treatments: Control; 50-COOH beads $\left(25 \mu \mathrm{g} \cdot \mathrm{mL}^{-1}\right)$; 50- $\mathrm{NH}_{2}$ beads $\left(10 \mu \mathrm{g} \cdot \mathrm{mL}^{-1}\right) ; 50-\mathrm{NH}_{2}$ beads $\left(25 \mu \mathrm{g} \cdot \mathrm{mL}^{-1}\right)$. Lipid composition was expressed as the mass percentage of each class to the total lipid content $(n=4$; means \pm SD). ANOVA method was used to compare treatments with Tukey HSD for pairwise comparisons at the 5\% level; *: $\mathrm{p}<$ 0.01. PE: phosphatidylethanolamine, PI: phosphatidylinositol, PSer: phosphatidylserine, CL: cardiolipin; CAEP: ceramide amino-ethylphosphonate, PC: phosphatidylcholine. 
Treatments

\begin{tabular}{ccccc}
\cline { 2 - 5 } & Control & $\begin{array}{c}50-\mathrm{COOH}(25 \\
\left.\mu \mathrm{g} \cdot \mathrm{mL}^{-1}\right)\end{array}$ & $\begin{array}{c}50-\mathrm{NH}_{2}(10 \\
\left.\mu \mathrm{g} \cdot \mathrm{mL}^{-1}\right)\end{array}$ & $\begin{array}{c}50-\mathrm{NH}_{2}(25 \\
\left.\mu \mathrm{g} \cdot \mathrm{mL}^{-1}\right)\end{array}$ \\
\hline \% Triglycerides & $1.59 \pm 0.76$ & $1.66 \pm 0.49$ & $1.56 \pm 0.65$ & $1.67 \pm 0.63$ \\
\% Sterols & $7.04 \pm 0.60$ & $6.79 \pm 0.48$ & $6.93 \pm 0.90$ & $6.37 \pm 0.30$ \\
\% Free fatty acids & $0.18 \pm 0.09$ & $0.14 \pm 0.01$ & $0.16 \pm 0.02$ & $0.11 \pm 0.01$ \\
\% PE & $23.13 \pm 0.76$ & $23.27 \pm 0.50$ & $23.24 \pm 0.84$ & $23.03 \pm 0.70$ \\
\% PI+CAEP & $18.90 \pm 1.24$ & $19.19 \pm 1.20$ & $19.15 \pm 1.51$ & $18.99 \pm 0.79$ \\
\% PSer & $6.61 \pm 0.28$ & $6.50 \pm 0.17$ & $6.85 \pm 0.20$ & $7.52 \pm 0.17 *$ \\
\% CL & $5.65 \pm 0.40$ & $5.97 \pm 0.23$ & $5.70 \pm 0.03$ & $5.66 \pm 0.16$ \\
\% PC & $36.90 \pm 0.55$ & $36.49 \pm 1.21$ & $36.40 \pm 0.42$ & $36.64 \pm 0.77$ \\
\% Membrane & $98.23 \pm 0.03$ & $98.20 \pm 0.05$ & $98.28 \pm 0.07$ & $98.22 \pm 0.02$ \\
\% Storage & $1.77 \pm 0.72$ & $1.80 \pm 0.50$ & $1.72 \pm 0.63$ & $1.78 \pm 0.62$ \\
PC/PE & $1.60 \pm 0.07$ & $1.57 \pm 0.06$ & $1.57 \pm 0.04$ & $1.59 \pm 0.07$ \\
$\begin{array}{c}\text { Total lipid content } \\
\text { (mg.109 spermatozoa }\end{array}$ & $4.03 \pm 0.24$ & $3.79 \pm 0.50$ & $4.20 \pm 0.72$ & $3.97 \pm 0.20$ \\
\hline 1) & & & & \\
\hline
\end{tabular}

Figure captions

A

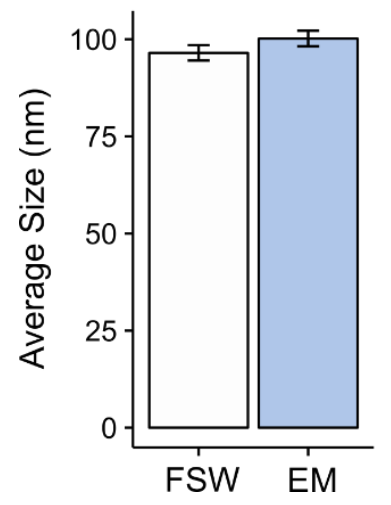

B

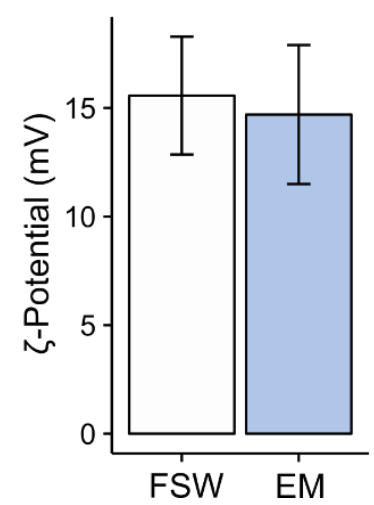

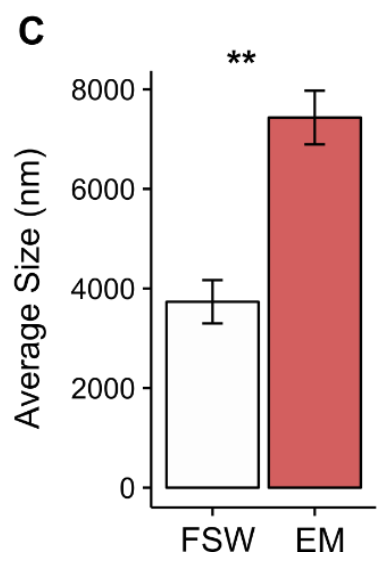

D

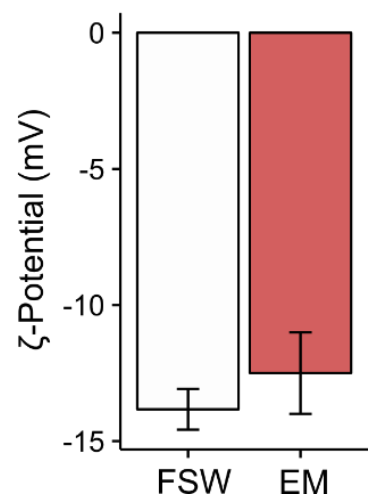

Figure 1. Size (nm; A and C) and $\zeta$-potential (mV; B and D) in filtered seawater (FSW, from Tallec et al., 2018) and the experimental medium (EM, present study) of two $50 \mathrm{~nm}$ nano-PS: 50- $\mathrm{NH}_{2}$ beads (A and $\left.\mathrm{B}\right)$; 50-COOH beads ( $\mathrm{C}$ and $\left.\mathrm{D}\right)$. Data are given as means $\pm \mathrm{SD}(\mathrm{n}=3)$. The $t$-test method was used to compare data between FSW and EM (** = p-value $<0.01)$. 

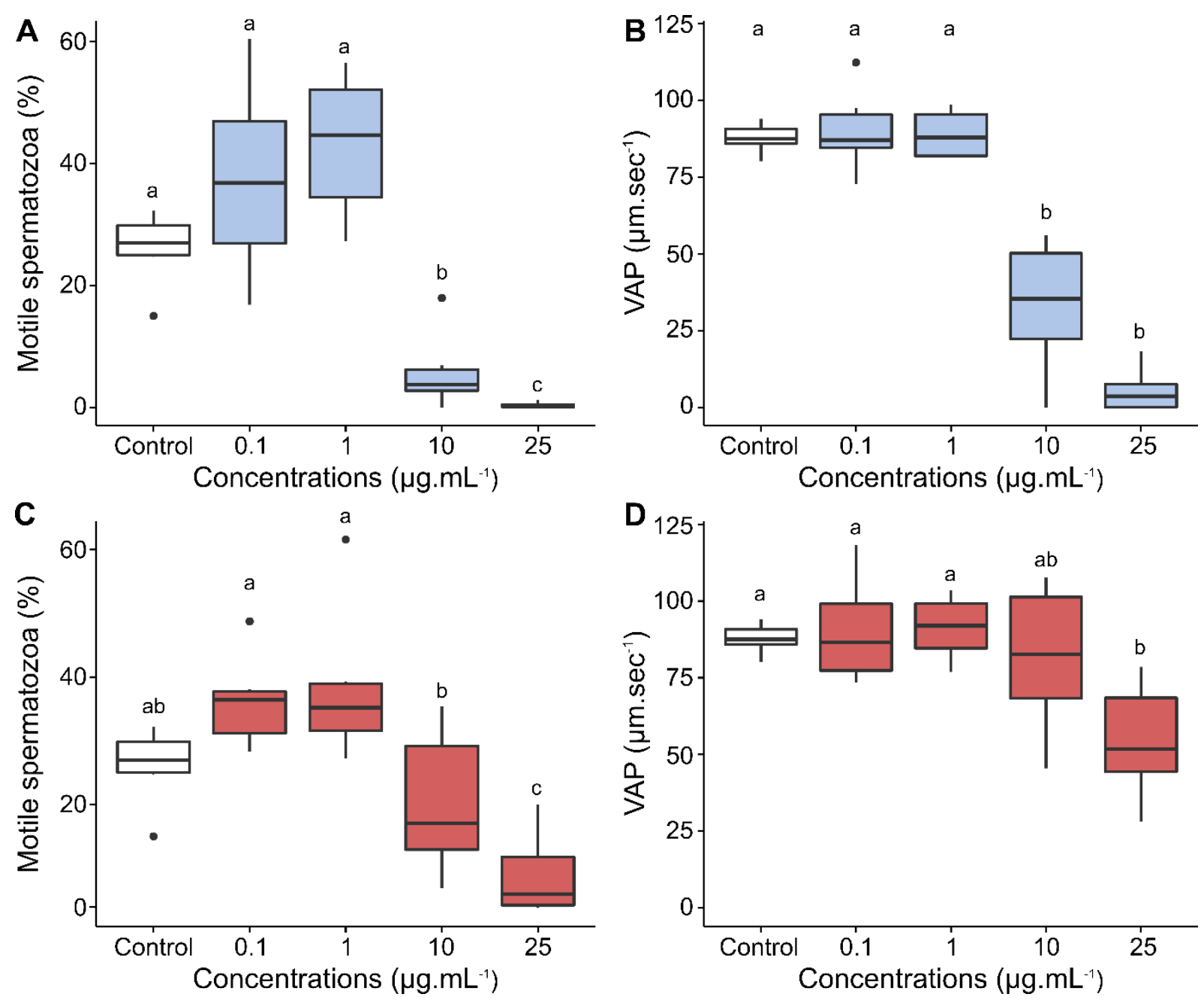

Figure 2. Percentage of motile spermatozoa (\%; A and C) and velocity of the average path (VAP; $\mu \mathrm{m} . \mathrm{sec}^{-1}$; B and D) of oyster spermatozoa after $1 \mathrm{~h}$ of exposure to $50-\mathrm{NH}_{2}$ (blue, A and B) and 50-COOH beads (red, C and D) at five concentrations: 0 (Control), 0.1, 1, 10, and 25 $\mu \mathrm{g} \cdot \mathrm{mL}^{-1} . \mathrm{N}=6$. ANOVA (A, C and D) or Kruskal-Wallis tests (B) with pairwise comparisons were made between treatments at the 5\% level; homogeneous groups share the same letter. 

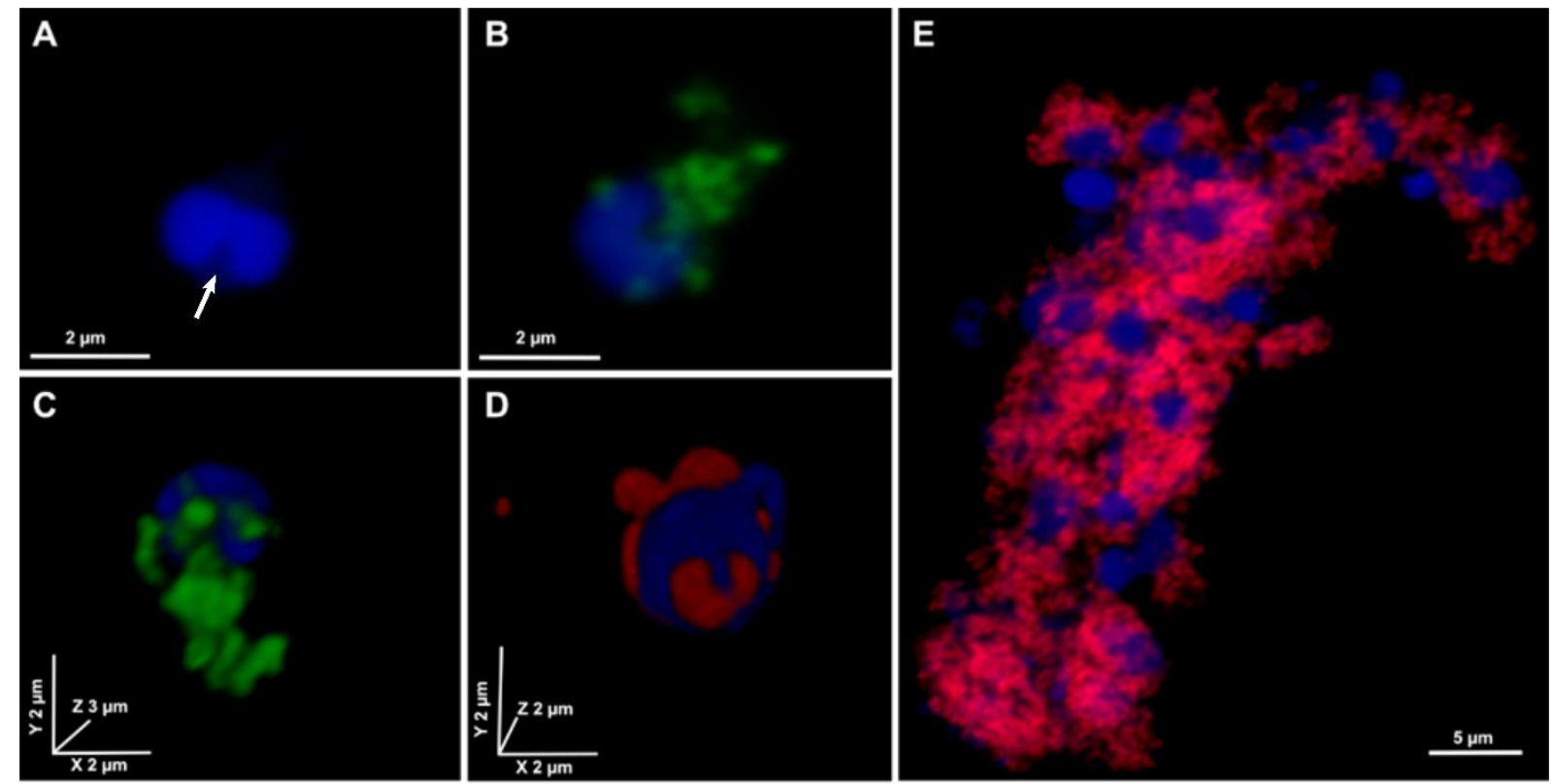

Figure 3. Confocal laser scanning microscopy of oyster spermatozoa (blue) after $1 \mathrm{~h}$ of exposure to nano-PS beads: (A) Control treatment; (B and C) Adhesion of 50- $\mathrm{NH}_{2}$ beads (green; $25 \mu \mathrm{g} \cdot \mathrm{mL}^{-1}$ ) on the spermatozoa head; (D) Adhesion of 50-COOH beads (red; $25 \mu \mathrm{g} . \mathrm{mL}^{-1}$ ) on the spermatozoa head and (E) Observation of spermatozoa embedded in microscale aggregates of 50-COOH beads. The arrow shows the location of the acrosome. Size is represented by the scale bar. 

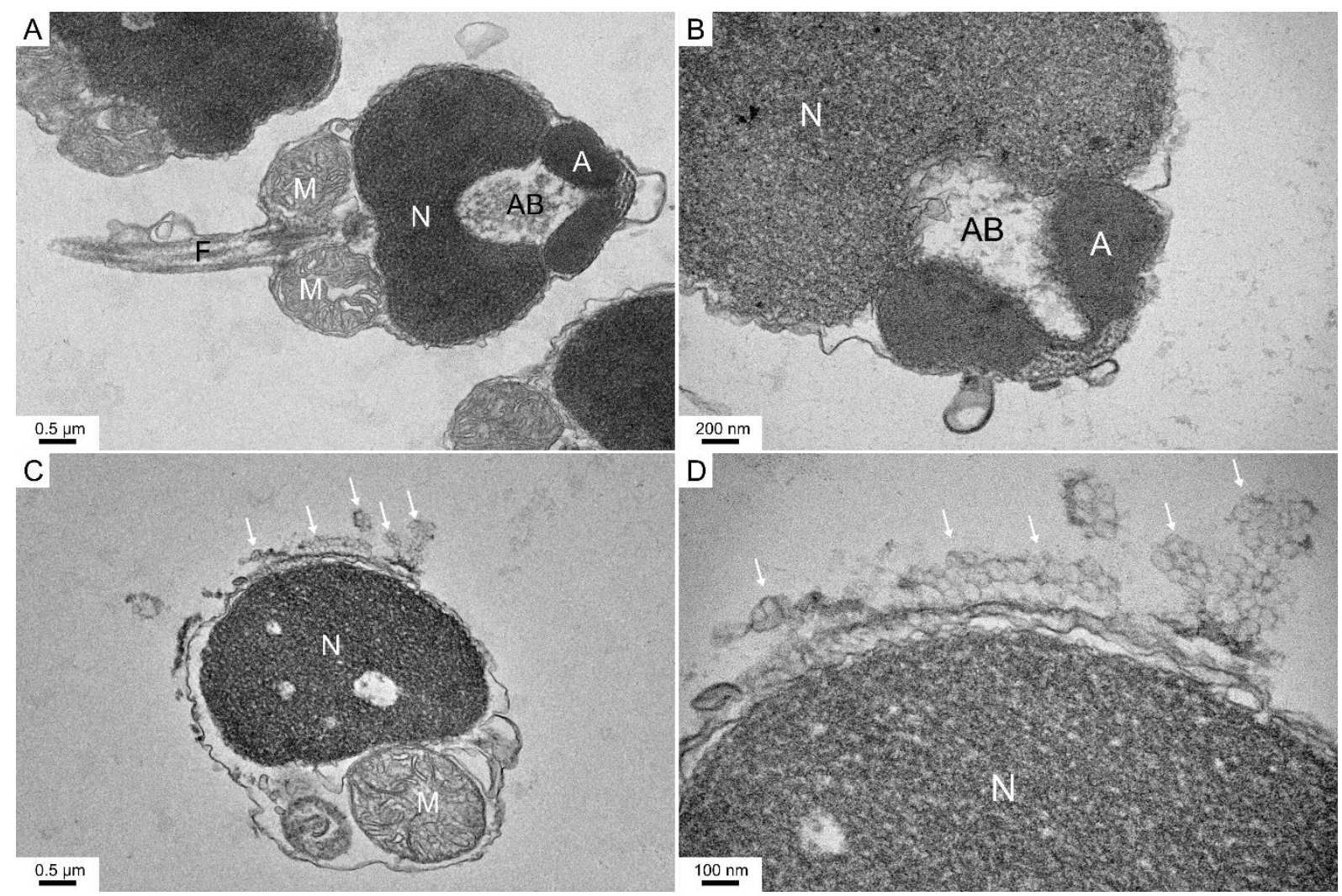

Figure 4. Transmission electron microscopy observations of oyster spermatozoa after $1 \mathrm{~h}$ of exposure to nano-PS beads. (A and B) Longitudinal sections of spermatozoa from the control treatment; (C and D) Longitudinal sections of spermatozoa exposed to $25 \mu \mathrm{g} \cdot \mathrm{mL}^{-1}$ of $50-\mathrm{NH}_{2}$ beads. White arrows indicate adhesion of $50-\mathrm{NH}_{2}$ to the spermatozoa membrane. A: Acrosome; AB: Axial body; N: Nucleus; M: Mitochondria; F: Flagellum. Size is represented by the scale bar. 

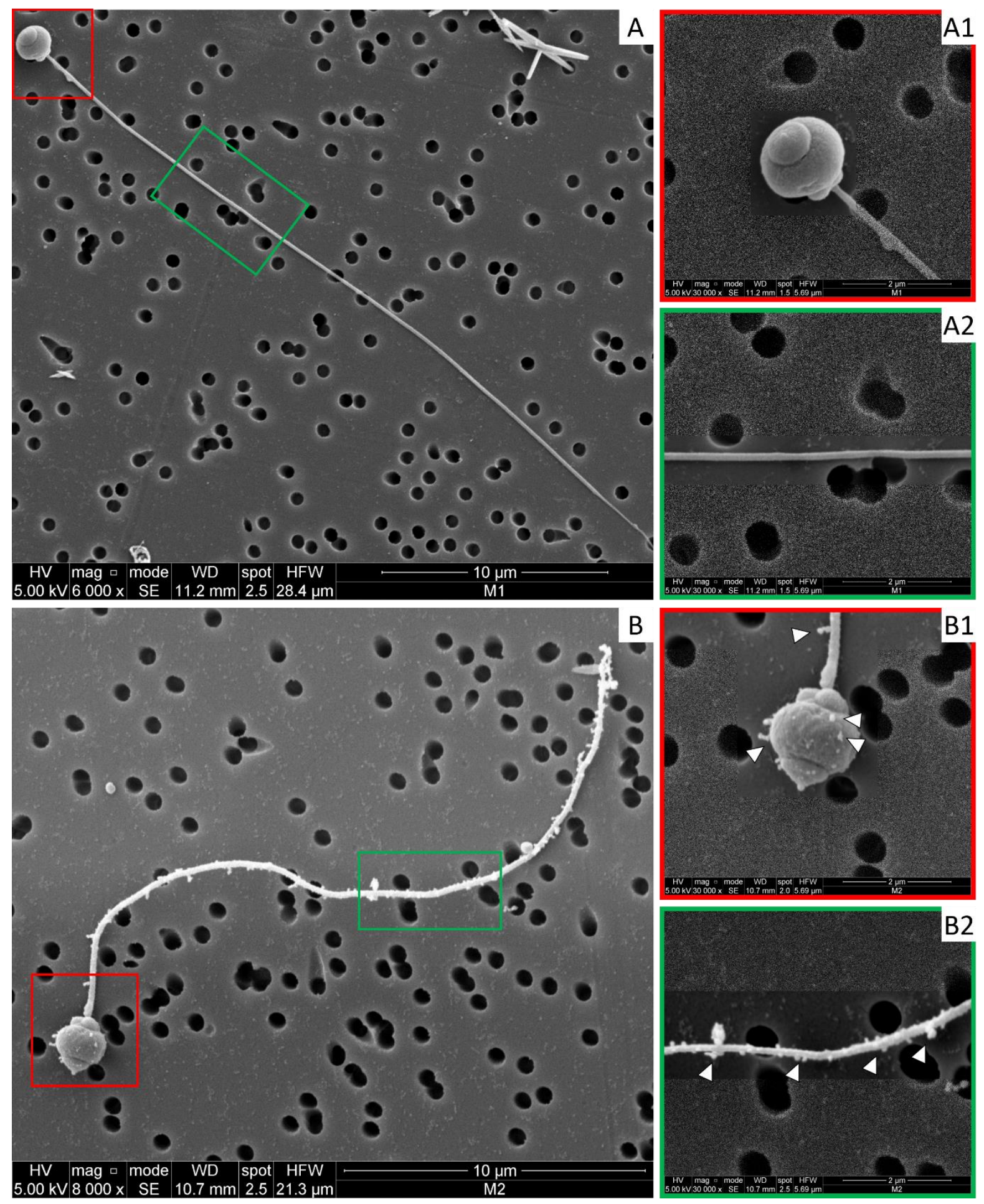

Figure 5. Scanning electron microscopy observations of oyster spermatozoa after $1 \mathrm{~h}$ of exposure to nano-PS beads. (A, A1 and A2) Spermatozoa from the control treatment; (B, B1 and B2) Spermatozoa exposed to $25 \mu \mathrm{g} \cdot \mathrm{mL}^{-1}$ of $50-\mathrm{NH}_{2}$ beads. White arrows indicate adhesion of $50-\mathrm{NH}_{2}$ beads to the spermatozoa head and flagellum. Size is represented by the scale bar. 

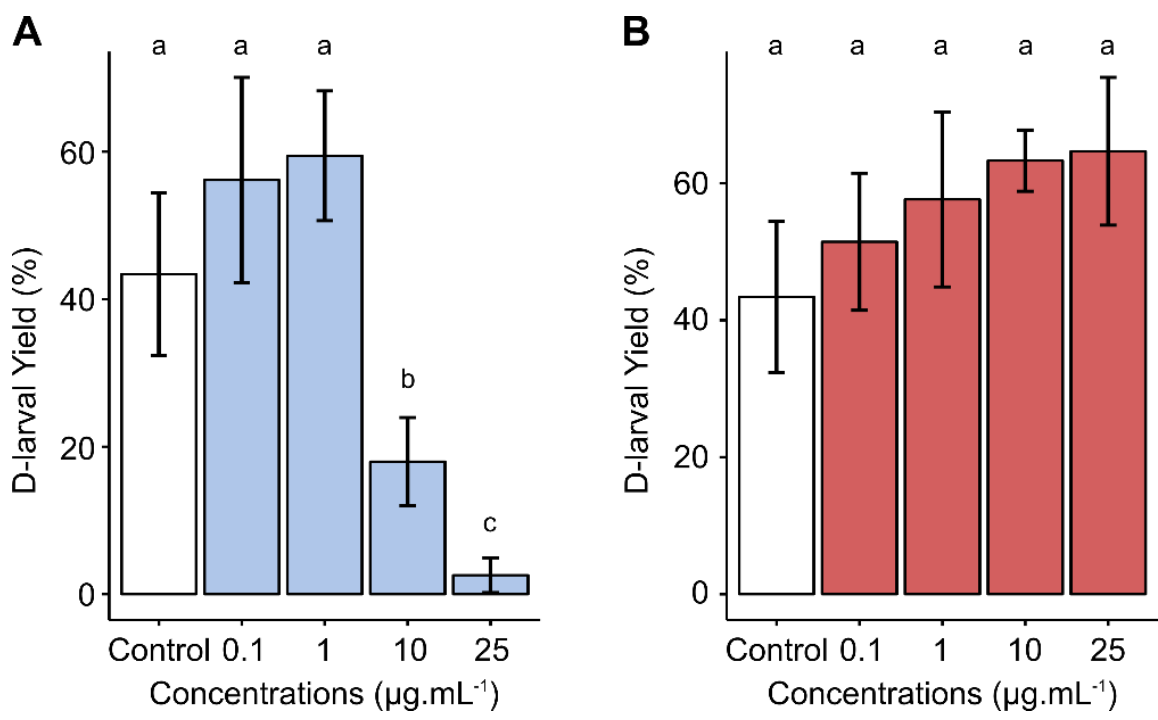

Figure 6. D-larval yield obtained following fertilization with spermatozoa exposed to five concentrations ( 0 - Control, $0.1,1,10$, and $\left.25 \mu \mathrm{g} \cdot \mathrm{mL}^{-1}\right)$ of $50-\mathrm{NH}_{2}$ (A) and 50-COOH beads (B). Data are given as means \pm SD $(n=6)$. ANOVA and pairwise comparisons were made between treatments using Tukey's HSD at the 5\% level; homogeneous groups share the same letter.
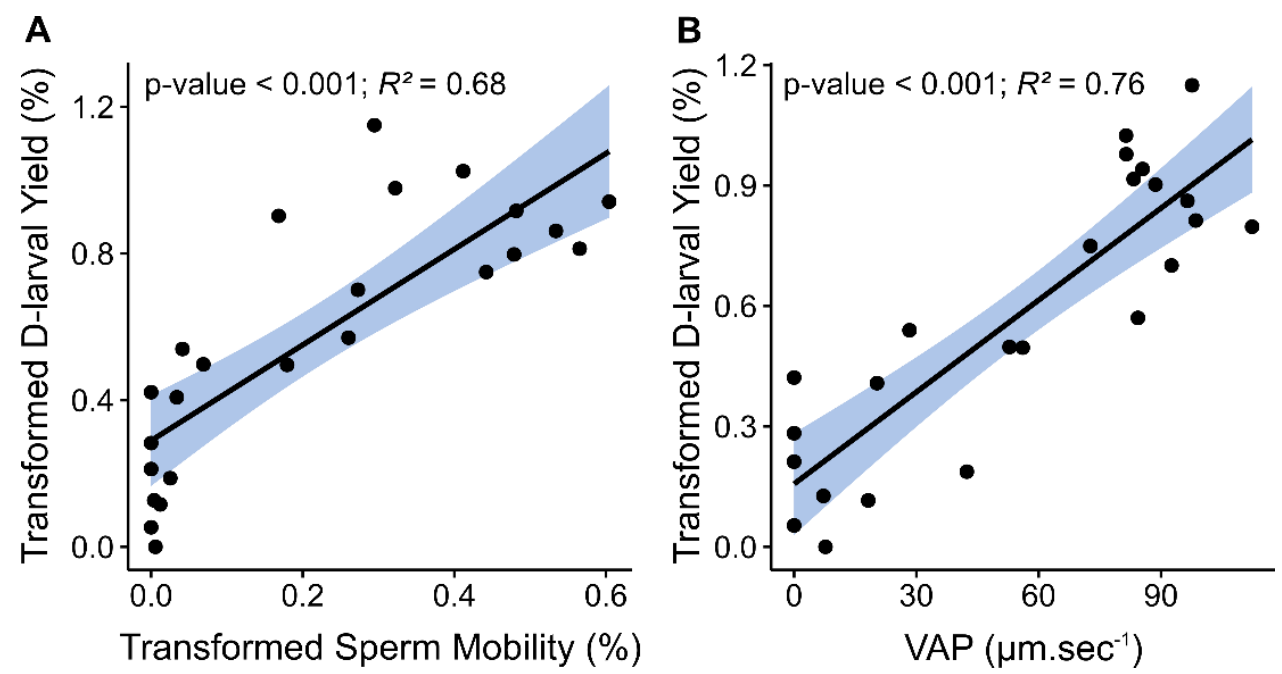

Figure 7. Correlations between spermatozoa motility (A) or VAP (B) and the D-larval yield after spermatozoa exposures to $50-\mathrm{NH}_{2}$ beads. Data used for the graphical representation were the data transformed as described in the materials and methods part. Statistical analyses were performed with the Pearson test at the $5 \%$ level $(n=6)$. 